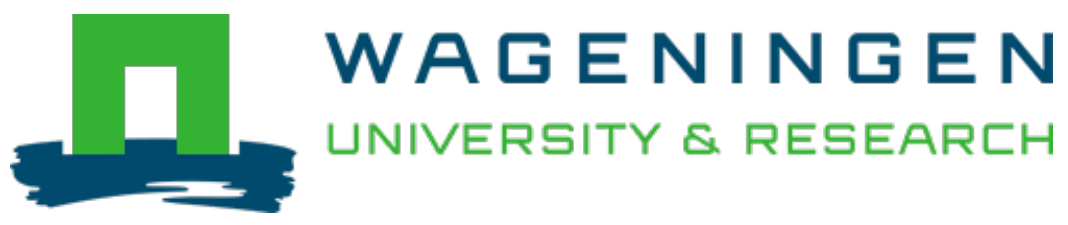

\title{
Responses of resources and consumers to experimental flow pulses in a temporary Mediterranean stream
}

\author{
Science of the Total Environment \\ Lobera, Gemma; Pardo, Isabel; García, Liliana; Garcia, Celso; Ribeiro, Ludmilla O. et al \\ https://doi.org/10.1016/j.scitotenv.2020.141843
}

This publication is made publicly available in the institutional repository of Wageningen University and Research, under the terms of article $25 \mathrm{fa}$ of the Dutch Copyright Act, also known as the Amendment Taverne. This has been done with explicit consent by the author.

Article 25 fa states that the author of a short scientific work funded either wholly or partially by Dutch public funds is entitled to make that work publicly available for no consideration following a reasonable period of time after the work was first published, provided that clear reference is made to the source of the first publication of the work.

This publication is distributed under The Association of Universities in the Netherlands (VSNU) 'Article $25 \mathrm{fa}$ implementation' project. In this project research outputs of researchers employed by Dutch Universities that comply with the legal requirements of Article $25 \mathrm{fa}$ of the Dutch Copyright Act are distributed online and free of cost or other barriers in institutional repositories. Research outputs are distributed six months after their first online publication in the original published version and with proper attribution to the source of the original publication.

You are permitted to download and use the publication for personal purposes. All rights remain with the author(s) and / or copyright owner(s) of this work. Any use of the publication or parts of it other than authorised under article $25 \mathrm{fa}$ of the Dutch Copyright act is prohibited. Wageningen University \& Research and the author(s) of this publication shall not be held responsible or liable for any damages resulting from your (re)use of this publication.

For questions regarding the public availability of this publication please contact openscience.library@wur.nl 


\title{
Responses of resources and consumers to experimental flow pulses in a temporary Mediterranean stream
}

\author{
Gemma Lobera $^{\mathrm{a}, *}$, Isabel Pardo ${ }^{\mathrm{b}}$, Liliana García ${ }^{\mathrm{b}}$, Celso Garcia ${ }^{\mathrm{a}}$, Ludmilla O. Ribeiro ${ }^{\mathrm{c}}$, Piet F.M. Verdonschot ${ }^{\mathrm{d}, \mathrm{e}}$ \\ a Department of Geography, University of the Balearic Islands, Palma, Illes Balears, Spain \\ b Department of Ecology and Animal Biology, University of Vigo, Vigo, Spain \\ c Universidade Regional Integrada do Alto Uruguai e das Missões, Brazil \\ d Freshwater Ecology Group, Wageningen Environmental Research, Droevendaalsesteeg 3, Wageningen, the Netherlands \\ e Freshwater and Marine Ecology, IBED, University of Amsterdam, Amsterdam, the Netherlands
}

\section{H I G H L I G H T S}

- Resources and benthic invertebrates showed high resistance to the flow pulse.

- The most disturbed site was the groundwater spring, fed with less dynamic flow.

- The hyporheic zone appears to be the main source of colonizers.

- Longer flood periods in autumn affect invertebrate resilience.

\section{A R T I C L E I N F O}

\section{Article history:}

Received 27 June 2020

Received in revised form 18 August 2020

Accepted 19 August 2020

Available online 24 August 2020

Editor: Damia Barcelo

\section{Keywords:}

Temporary streams

Floods

Periphyton

Benthic organic material

Invertebrates

Hyporheos
GRAPHICALA B STRACT

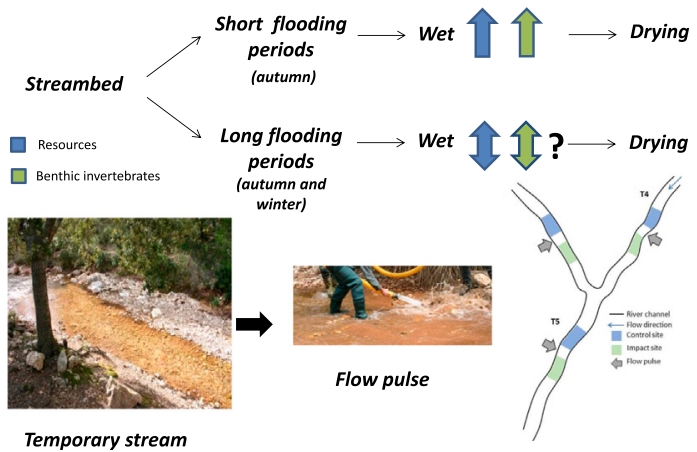

\section{A B S T R A C T}

Determining the resistance and resilience of resources and benthic invertebrates connected to instream refuges and species re-colonization in post-flood periods may help to elucidate mechanisms behind community recovery. This experiment simulated flow pulses in a small temporary stream in an extremely wet year, using upstream control and downstream flooded reaches at three sites in order to assess community resistance and resilience (benthos and drift), and analyse resources (periphyton and benthic organic matter) and invertebrates at pre- and post-flood time periods. The hyporheos was sampled in order to explore species exchanges with benthos. Fewer resources and benthic invertebrates at the beginning of the experiment were found than in previous studies when base flow conditions prevailed. Resource stocks and benthic invertebrates showed high resistance to the flow pulse. Interestingly, there was low resilience of benthic organic matter to natural seasonal flooding. Chlorophyll $a$ did not recover after experimental floods; instead, it was reduced after floods, despite the more benign flow conditions and non-limiting irradiance levels, pointing to top-down control by consumers. Additionally, the experimental flood significantly disturbed only the invertebrate composition in the groundwater-fed stream, which was inhabited by the fewest adapted-to-flood-disturbances macroinvertebrates. Despite the low resilience observed, richness and densities of benthos increased during the study, evidencing progressive colonization. Around $50-60 \%$ of macroinvertebrates were present in both benthos and hyporheos. Richness increased after flooding, suggesting that the hyporheic zone could be the main source of colonizers. Three species traits characterized the hyporheos: small size, cocoons and feeders of microorganisms within the fine sediment matrix. The main results indicate that longer-than-normal flood periods in early spring may constrain invertebrate succession before the next summer drought in temporary streams. This study underscores the importance of

\footnotetext{
* Corresponding author.

E-mail address: g.lobera@uib.cat (G. Lobera).
} 
hyporheic fauna as a significance source of colonizers, highlighting the importance of connectivity to the groundwater.

\section{Introduction}

Under a Mediterranean climate, rivers are physically, chemically, and biologically shaped by sequential hydrological disturbances of flooding and drying, which can vary from year to year in intensity and duration (Gasith and Resh, 1999). Spring-fed Mediterranean streams can even be intermittent or ephemeral, though groundwater can moderate seasonal flow fluctuation (Williams, 2006). Intermittent rivers are useful models to investigate resistance to and recovery from both flood and drought disturbances. Biological community resistance is defined here as the ability to persist during a disturbance, whereas resilience is the ability to recover after disturbance (Lake, 2000). Community adaptations to drying have been widely reported in intermittent streams (e.g. Leigh et al., 2016; Cid et al., 2016), whereas adaptations to flooding have been paid much less attention (but see Hershkovitz and Gasith, 2013). It is widely recognised that climate change results in severe alterations to Mediterranean river flow regimes because of a decrease in the number of precipitation days (droughts) and an increase in days with heavy rains (floods) (Datry et al., 2016b). Consequently, Mediterranean environments are currently under significant threat from increasing variability in seasonal and inter-annual rainfall patterns (Candela et al., 2009; Cramer et al., 2018).

In Mediterranean rivers, drying ends with the onset of the rainy season in autumn, when water resumes in the channels (Gasith and Resh, 1999). Floods affect bed stability and channel morphology (Lobera et al., 2017), maintain the habitat for freshwater organisms and riparian vegetation (Arscott et al., 2000; Fraaije et al., 2015), homogenize water quality along the stream continuum (Tockner et al., 1999), and redistribute the biota (Lake, 2000). Floods can reduce invertebrateabundance and induce changes in community composition by displacement and mortality (Death and Winterbourn, 1995; McMullen and Lytle, 2012). Highly flood-prone rivers are generally dominated by taxa with behavioural traits or life histories that increase their resistance or facilitate fast recolonization (Scarsbrook, 2002; Greenwood and Booker, 2015). The reachscale effects of a flood depend on the availability of refugia provided by stable stream-bed areas, the hyporheic zone and hydraulic dead zones (Gibbins et al., 2007; Brouwer et al., 2019). The hyporheic zone may remain stable during floods and retains water after surface drying (Boulton et al., 1998; Lewandowski et al., 2019), offering a potential refuge for both floods and droughts in temporary streams. Several studies have evidenced active migration to the hyporheic zone during natural spates (Williams and Hynes, 1974; Dole-Olivier et al., 1997), prolonged high flows (Marchant, 1995) and experimental equivalents (Holomuzki and Biggs, 2000). Other studies have not found evidence of active migrations during floods, a result mainly attributed to inadequate habitat or disturbance-related factors (Boulton et al., 2004; Olsen and Townsend, 2005; Stubbington, 2012). Morphological and/or behavioural taxonspecific characteristics can restrict the active migration of certain taxa (Stubbington, 2012). Robertson and Wood (2010) identified traits associated with active migrant taxa as follows: no attachment, burrowing habit, depositional rheophily, high crawling rate, small ( $<9 \mathrm{~mm})$ at maturity, tegument respiration and vermiform shape (Marchant, 1988, 1995; Delucchi, 1989; Marmonier and Creuzé des Châtelliers, 1991). Stubbington (2012) concluded that only 'no attachment' is the trait all have in common.

Flooding in autumn, when the stream is at its lowest stage, is supposed to produce a greater impact on communities residing in temporary rivers than on communities residing in perennial rivers (Hershkovitz and Gasith, 2013). Autumnal floods reset the system, generating pulses of nutrients and rewetting organic material $(\mathrm{OM})$ events that characterise these systems as bioreactors (Datry et al., 2018), while initiating the succession of aquatic communities (Fisher et al., 1982). Autumn assemblages in temporary streams are mostly composed of drought-resistant lentic species which are more likely to be eliminated by strong floods (Hershkovitz and Gasith, 2013). In contrast, spring floods occur at a time when water has been in the channels for months, and the biotic communities can be at a fully developed state. A flood event in early spring after a dry autumn-winter (under low flow conditions) can severely disturb the aquatic community, while a flood event in early spring after a wet half-year (high flow conditions) adds more disturbances to the already disturbed community. This means that spring floods can influence, in very different ways, the annual development of the aquatic community in temporary streams.

Response and recovery of macroinvertebrate assemblages and resources to simulated flow pulses in a temporary stream on the island of Mallorca were examined. The main objectives were: (i) to test the resistance of resources (periphyton and benthic organic matter) and benthic invertebrates (richness, density and drift) to an experimental flow pulse, (ii) to assess resilience of invertebrates (benthic composition and biological traits) and resources to the flow pulse, (iii) to test temporal trends of resources and benthic invertebrates (richness, density and biological traits) to receding flows, and (iv) to explore the hyporheos contribution to benthic invertebrates under receding flows. The first prediction was that the experimental flow pulses would deplete the streambed from resources and invertebrates. A previous study executed in the same system indicated that resources and invertebrate richness and densities were high under normal spring base water levels (Álvarez and Pardo, 2009), and it was expected they would show low resistance to an experimental flow pulse at the reach level. Second, as the whole stream would maintain significant extension of aquatic habitats where resources and invertebrates would not be affected by the experimental flow pulses, a fast recovery (high resilience) was expected at the disturbed sites, as connectivity with close non-disturbed sites would ensure fast invertebrate aquatic dispersion and colonization. Third, it was predicted that there would be a gradual shift in trait representations, from flood- resistant traits after the flow pulses to droughtresistant traits, with decreasing flows towards summer.

\section{Methods}

\subsection{Study area}

The experiment was conducted in temporary streams located in the Ternelles basin $\left(11 \mathrm{~km}^{2}\right)$ in the northeastern part of the Tramuntana range on the island of Mallorca (Fig. 1). The Ternelles basin is one of the few non-impaired river systems of the Tramuntana range on Mallorca (García et al., 2014). Two sites were situated in the Ternelles stream (T4, T5), and one in the Gorg Blau stream (GB), a tributary of the Ternelles. The most upstream site T4 is situated $2 \mathrm{~km}$ downstream of the Ternelles springs ( $265 \mathrm{~m}$ a.s.l.); the second site T5 is positioned around $300 \mathrm{~m}$ downstream of T4. The third site GB is located around $300 \mathrm{~m}$ upstream of the confluence with the Ternelles. GB water originates from two springs of nearly permanent discharge. The duration of the drought in the studied spring-fed streams depends on the amount of groundwater supplied by the springs, ranging between 0 and 4 months. Therefore, the discharge strongly relies on the amount of rainfall in previous months (Álvarez and Pardo, 2007). The precipitation sum of the six months (autumn and winter) previous to the experiment was $1143 \mathrm{~mm}$, much higher than the annual long-term average (i.e. $838 \mathrm{~mm}$ for the period 1976-2006). The riparian vegetation at the 
a) Study reach
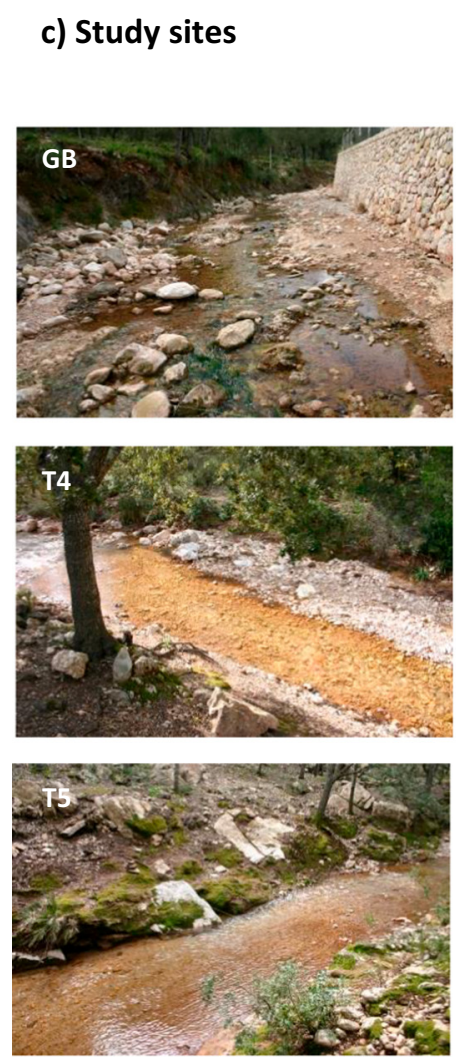

b) Location
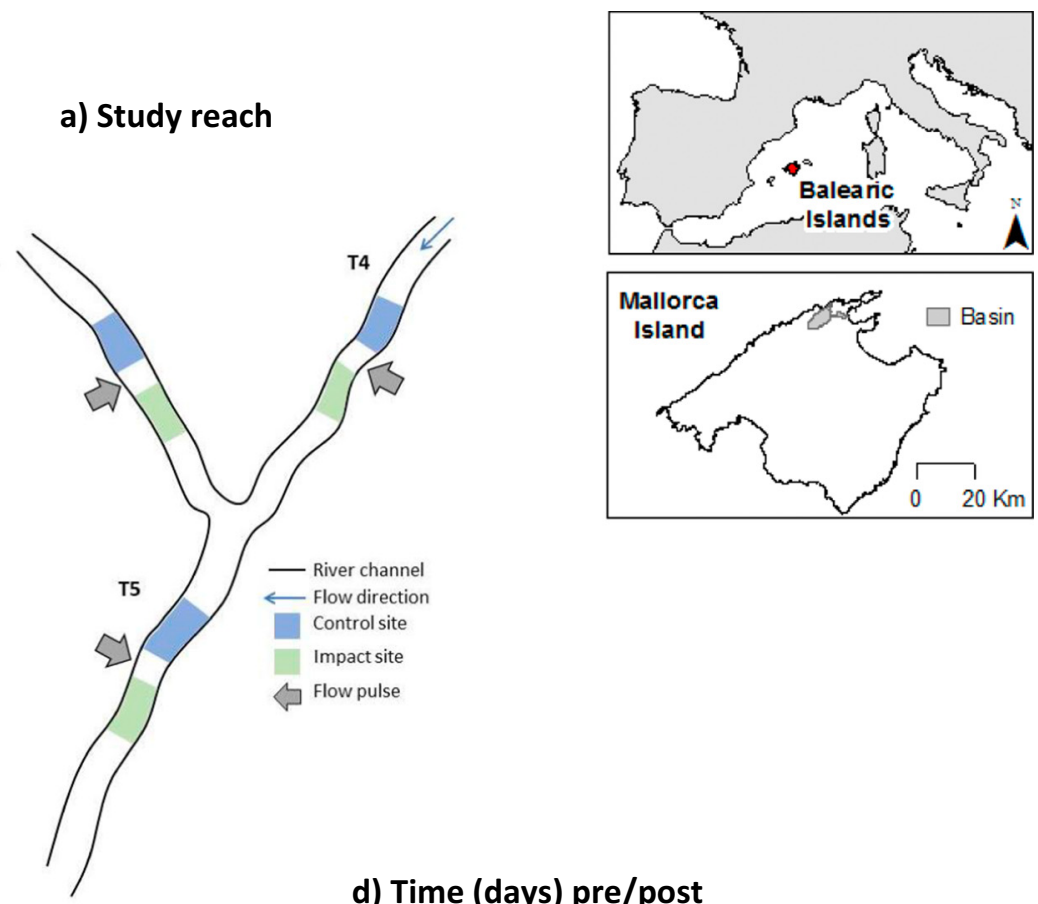

d) Time (days) pre/post

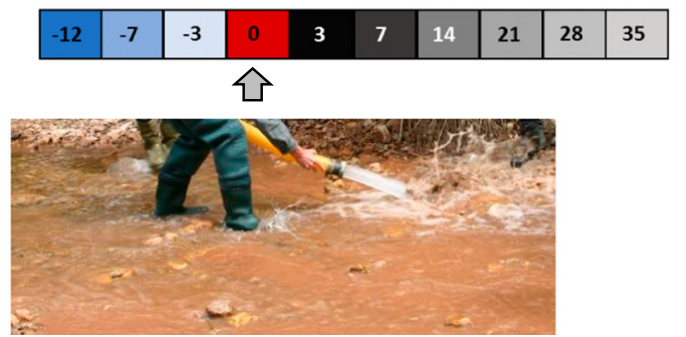

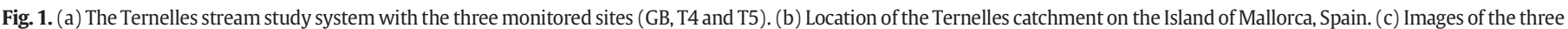

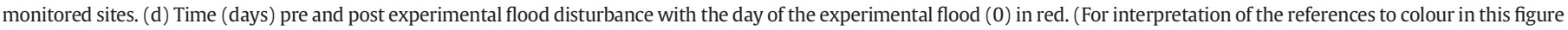
legend, the reader is referred to the web version of this article.)

studied sites mainly consisted of the evergreen Holm oak Quercus ilex L. which mainly contributes to the amount of organic matter input to the stream system.

\subsection{Experimental design and sampling}

The experimental manipulation used here allowed the application of a more robust paired before-after, control-impact (BACI) analysis design (see Downes et al., 2002) to establish if there were consistent impacts on resources and benthic invertebrates to simulated flow pulses. At each site (Fig. 1), an upstream control and a downstream flood reach was marked (on average $23.5 \mathrm{~m}$ in length). In each reach a regular grid was established by attaching thin ropes to nails hammered into the stream bank, and grid cells (between 60 and 90 cells per reach) were randomly sampled once. Samples were taken simultaneously in control and flood reaches on March 8, 13 and 17 before the experimental flow pulse, and on March 20, 23, 27, April 3, 10, 17, 24, and May 1, 2006, after the experimental flow pulse. The flood simulation took place on March 20, 2006. The first site where the flow pulse was simulated was the downstream reach $\mathrm{T} 5$ to ensure independence of initial flow pulse results at T5 from the upstream reaches (T4 and GB), each of them located in a stream tributary branch (Fig. 1). The flow pulse was then performed at T4 and after at GB. The streambed at each site was flushed with a water hose (discharging $4.4 \mathrm{~L} \mathrm{~s}^{-1}$ ) fed by a water tank containing $10.000 \mathrm{~L}$ of water collected downstream in the Ternelles stream. The water hose was managed by a person walking zig-zag along the full flood reach and disrupting the entire streambed (Fig. 1).

The level of disturbance attained in this experiment was previously established by performing an experimental flow pulse at a downstream reach below T5. For that experimental flow pulse, the displacement of 18 stones (on average $7.9 \pm 0.2 \mathrm{~cm}$ in diameter) which had been previously placed in three lines at 3.2, 10.8 and $17.6 \mathrm{~m}$ from the hose mouth was measured. At a discharge of $4.4 \mathrm{~L} \mathrm{~s}^{-1}$ the particles moved, on average, $1.63 \pm 0.07 \mathrm{~m}, 1.11 \pm 0.11 \mathrm{~m}$, and $0.51 \pm 0.13 \mathrm{~m}$ at $3.2 \mathrm{~m}, 10 \mathrm{~m}$, and $17 \mathrm{~m}$ distance from the hose, respectively. This flow pulse was considered to represent a low-medium flood event because only small particles were transported downstream. A stronger disturbance would have moved most of the stones outside the studied reaches.

\subsection{Physicochemical characteristics}

Physical-chemical variables were obtained in the field with portable meters, measuring water temperature and $\mathrm{pH}$ (Thermo Orion 290+), electric conductivity at $25{ }^{\circ} \mathrm{C}$ (Thermo Orion $115 \mathrm{~A}+$ ) and dissolved 
oxygen (WTW Oxi 197 oxymeter). On each sampling date, water samples were collected from the three sites, stored in polypropylene bottles, cooled in dark conditions at $4{ }^{\circ} \mathrm{C}$ and transported to the laboratory. Water chemical analyses were carried out following standard methods (APHA, 1989), examining nitrates $\left(\mathrm{N}_{-} \mathrm{NO}_{3}^{-}\right)$, phosphates $\left(\mathrm{P}_{-} \mathrm{PO}_{4}^{3-}\right)$ silicon dioxide $\left(\mathrm{SiO}_{2}\right)$ and DOC using an auto-analyzer for nutrient quantification (Auto-Analyzer3, Bran + Luebbe, Germany).

Discharge was measured at each sampling site before, during and after the experimental flow pulse. Discharge $\left(\mathrm{L} \mathrm{s}^{-1}\right)$ was calculated by multiplying the stream cross sectional area by the integrated mean velocity ( $n=3$ recordings of $1 \mathrm{~min}$ ) recorded at fixed transversal positions per site and sampling time. When taking Surber samples for invertebrates, flow velocity $\left(\mathrm{m} \mathrm{s}^{-1}\right)$ and depth $(\mathrm{cm})$ were measured in the center of the Surber square. Particle size classes were visually estimated within the Surber area. The five classes matched the modified Wentworth scale (Minshall, 1984): clay-silt $<0.0625 \mathrm{~mm}$, sand $(0.0625-2 \mathrm{~mm})$, pebbles $(2-64 \mathrm{~mm})$, cobbles (64-256 mm), boulders (>256 mm), and bedrock (rock exposures).

Average change in discharge over time was calculated between sampling dates per site (Discharge $_{\mathrm{t}}$ - Discharge $_{\mathrm{t}-1}$, where $t$ is sampling date) to assess flow tendency and the inflow of groundwater (Berg and Allen, 2008).

\subsection{Autochthonous and allochthonous resources}

To quantify the change in resources, epilithon chlorophyll $a$ (Chl a) and total organic matter (ash free dry mass, AFDM) were taken at each sampling. Epilithon was sampled by scraping five stones, picked from the respective grid cell selected for invertebrate sampling. Two areas of $8.05 \mathrm{~cm}^{2}$ each were scraped off with a nylon toothbrush, one for Chl $a$ analysis and the other for AFDM. The samples were cooled at $4{ }^{\circ} \mathrm{C}$ and transported to the lab. Chlorophyll $a$ was extracted in $90 \%$ acetone in the dark at low temperature and was measured spectrophotometrically (Unicam UV/VIS UV4 Spectrometer, Cambridge, UK). Values were determined using the equations described in Lorenzen (1967). Ash free dry mass samples were filtered through a preweighed $0.45 \mu \mathrm{m}$ pore size Whatman GF/C glass fiber filter, dried at $105^{\circ} \mathrm{C}$ for $24 \mathrm{~h}$ and reweighed and, after measuring the dry mass, filters were incinerated for $1.5 \mathrm{~h}$ at $505^{\circ} \mathrm{C}$ and reweighed to obtain AFDM.

Benthic organic matter (BPOM) was collected from each of the Surber samples and was divided into coarse benthic particulate organic matter ( $\mathrm{CBPOM}>1 \mathrm{~mm}$ ) and fine benthic particulate organic matter (FBPOM $<1 \mathrm{~mm}-0.1 \mathrm{~mm}$ ) using a $1-\mathrm{mm}$ size sieve. After removing organisms, the organic detritus was separated by elutriation from the inorganic fractions. Both fractions were dried at $80{ }^{\circ} \mathrm{C}$ over $48 \mathrm{~h}$ until a constant weight, were weighted and expressed as dry mass $\left(\mathrm{g} \mathrm{m}^{-2}\right)$.

\subsection{Invertebrate processing and identification}

\subsubsection{Benthic invertebrates}

Benthic invertebrates were collected at each sampling per reach using a Surber sampler $(20 \times 20 \mathrm{~cm}$ and $100 \mu \mathrm{m}$ mesh size $)$. Four replicate samples were taken at control and flood reaches before and after the simulated flow pulse. Altogether, 240 samples were collected from the three study sites. The Surber samples were washed through granulometric sieves of $100 \mu \mathrm{m}$, and $0.50,1$ and $5 \mathrm{~mm}$. The invertebrates were colored (rose Bengal), to facilitate sorting by hand, and preserved in 70\% alcohol. Identification was at the lowest possible taxonomic level, except for Oligochaeta, Hirudinea, Hydracarina and Diptera (family, subfamily). The invertebrate counts reflect densities per Surber area.

\subsubsection{Drifting invertebrates}

During the experimental flow pulse, drift samples (three $10 \mathrm{~min}$ replicates) were taken using drift nets $(20 \mathrm{~cm}$ high $\mathrm{x} 50 \mathrm{~cm}$ wide) simultaneously at the end of each control and flood reach. Water velocity and water level were measured $(n=3)$ at the mouth of each drift net. Drifting invertebrates were expressed as individuals per $\mathrm{m}^{3}$ of filtered water.

\subsubsection{Hyporheic invertebrates}

Hyporheos was sampled twice (April 26 and May 1, 2006) in T5 and T4 and once in GB (May 1) at control reaches; due to sampling time limitations, this was considered enough to describe the hyporheos composition and to compare it with the benthos. Samples were taken with a manual pump inserted into the bed substrate, down to a depth of $15-30 \mathrm{~cm}$, and filtering a known volume of water through a $100 \mu \mathrm{m}$ size net. Invertebrates from the hyporheos were expressed as individuals per $\mathrm{m}^{3}$.

\subsubsection{Biological traits}

Nine biological traits were used to examine the effect of hydrological variability: organism size, life cycle duration, number of life cycles per year, dispersal strategy, resistance form, respiratory systems, food type, feeding habits, and locomotion and substrate relation (Table S1; Tachet et al., 2010; Cid et al., 2016). The trait profile was obtained by weighting the individual trait modalities of each taxon by their logarithmic $(x+1)$ abundance in the sample. Next, the sum of weighted abundances per modality per sample was expressed as a frequency (Descloux et al., 2014). For taxa for which there is not information on traits ( $<15 \%$ of taxons), family level scores were used by averaging trait values of all genera with trait information in a given family (as Sarremejane et al., 2017).

\subsection{Data analyses}

First, we analyzed if the invertebrate composition was similar among studied sites. Non-metric multidimensional scaling (nMDS; Kruskal, 1964) was applied to the three complete datasets: a) benthic b) drift and c) hyporheos invertebrate composition. An nMDS ordination was performed on $\log (\mathrm{x}+1)$-transformed abundance data using the Bray-Curtis similarity index. Analysis of similarity (ANOSIM) was applied to assess differences in invertebrate assemblages. These analyses were performed using the functions metaMDS and ANOSIM from the vegan package in R and PRIMER v.6 software (Clarke and Gorley, 2006).

Second, indicator species analysis (ISA) was performed to identify the trait category associated with both the hyporheic and the benthic zone in the stream reaches, using the function multipatt of the indicspecies package in R (De Cáceres and Legendre, 2009; De Cáceres et al., 2010). Indicator species analysis calculates an Indicator Value (IndVal; Dufréne and Legendre, 1997), constrained between 0 and 1 , for each taxon or trait category corresponding to each group defined a priori. This index is the product of the specificity value (A; probability of existing only in a particular group) and the fidelity or sensitivity value $(B$; frequency of occurrence within a particular group). Species or trait categories with low IndVal were discarded, setting the threshold for the two components as suggested by De Cáceres et al. (2012): $\mathrm{A}=0.6$ and $\mathrm{B}=0.25$.

\subsubsection{Test the resistance of resources and benthic invertebrates to an exper- imental flow pulse (Objective 1)}

At each site, samples taken three days before the experimental flow pulse and $2 \mathrm{~h}$ after were compared, in order to analyse the resistance of the resources and benthic invertebrates. Temporal changes in the control reaches (three days before and $2 \mathrm{~h}$ after the experiment) were also analyzed, to measure variation in resources and invertebrate communities that occurred in the absence of the simulated disturbance. Wilcoxon matched-pairs tests were performed, a non-parametric test for contrasting before and after observations, on: i) resources (Chl $a$, AFDM, CBPOM and FBPOM); and ii) benthic invertebrates (richness, density and drift), using IBM SPSS Statistics 24 . To assess differences in drifting invertebrates, drift samples taken at control and flood reaches during the experimental flow pulse were used. 
2.6.2. Assess resource and invertebrate (benthic composition and biological traits) resilience to the flow pulse (Objective 2)

First, unforeseen impacts of the flow pulses conducted at T4 and GB on the downstream site (T5) in the assessment of resources and invertebrates resilience were discarded. Wilcoxon matched-pairs tests were performed to assess potential impact on richness and density at T5 control reach between the $2 \mathrm{~h}$ after and the three days after samples, the last samples taken posterior to flow pulse manipulation at upstream reaches.

A Principal Response Curve (PRC) analysis was run per site (Van den Brink and Ter Braak, 1999) in order to test the effects of the simulated flow pulse on food resources (Chl $a$, AFDM epilithon and coarse and fine BPOM) and benthic invertebrates (composition and biological traits). Principal Response Curve is a multivariate method for the analysis of repeated measurement designs. It tests and displays treatment effects of a time series in comparison to a reference site (e.g. Van den Brink et al., 2009). The technique uses redundancy analysis and introduces interaction between sampling dates as covariables and treatment as explanatory variables (Van den Brink and Ter Braak, 1999). This divides the variance into parts that can be attributed to differences in time, to treatment differences in time, and to differences between replicates (Van den Brink et al., 2009). As a result, the PRC diagram contrasts each treatment in the vertical axis with the control across time. The RDA was accompanied by before-after-control-impact Monte Carlo permutation tests to detect significant effects of the explanatory variables on the resource amount of the samples for the entire time series (Van den Brink and Ter Braak, 1999). The PRC analyses were performed using $\mathrm{R}$ version 3.5.1 using the vegan package.

A set of species weights (on the right side of the diagram) shows the affinity of each species to the community response pattern offered by the PRC model (Leps and Smilauer, 2003 for further details). The higher the species weight, the stronger the species response to treatment. For a quantitative evaluation of the PRC analysis on each species, the quotient exp. $\left(b_{k} c_{d t}\right)$ was calculated, where $b_{k}$ is the species weight and $\mathrm{c}_{\mathrm{dt}}$ is the canonical coefficient at flood $d$ on sampling date $t$, as in García and Pardo (2017). This allowed estimation of the percentage of change in the abundance of a species in the experimentally flooded reach relative to the control, independent of its absolute abundance.

2.6.3. Test temporal trends of resources and benthic invertebrates (richness, density and biological traits) to receding flows (Objective 3)

To test the temporal response of resources, nonparametric TheilSen's regression method was performed, using mblm function in $\mathrm{R}$ (Theil, 1950; Sen, 1968), as the data was not normally distributed. In order to test benthic invertebrate responses, we performed linear regressions to richness, density values and biological traits over time. Prior to this, data were examined to determine whether they approximated a normal distribution, using both Shapiro-Wilk tests and plotting studentized residuals against a normal distribution. Data were log transformed when necessary. For biological traits analysis, only taxa presence/absence data was considered in this case, multiplied with specific trait values and divided by the total number of species present per sampling date. If previous PRC analysis indicated the absence of significant differences in species composition between control and flooded sites, we fused control and flooded replicates of benthic invertebrates (richness and density) per sampling time and then analyzed time trajectories with regression analyses (using IBM SPSS Statistics 24).

\subsubsection{Explore hyporheos composition contributions to benthic inverte-} brates under receding flows (Objective 4)

To ascertain the relationship between benthic invertebrate assemblages and the hyporheos with receding flows during the study, the presence of those taxa sampled in the hyporheos were crossed with those present in the benthos. Linear regression models were used to fit richness-dependent variables to discharge per site. Four dependent variables were calculated per sampling time: i) taxon richness in the benthic zone; ii) taxon richness common to both the benthic and hyporheic zone; iii) taxon richness observed only in the benthic zone (these taxa were never found in the hyporheic zone during the two sampling campaigns); iv) taxon richness observed in the hyporheic zone but never found in the benthic zone.

\section{Results}

\subsection{Environmental variables}

Mean discharge was higher in T4 $\left(35 \mathrm{~L} \mathrm{~s}^{-1}\right)$ than in GB $\left(25 \mathrm{~L} \mathrm{~s}^{-1}\right)$, and highest at T5 (46 $\mathrm{L} \mathrm{s}^{-1}$ ) after the two streams confluence (Table 1). Maximum discharge in T5 $\left(76 \mathrm{~L} \mathrm{~s}^{-1}\right.$ ) was registered three days before the flood experiment. In T4, the discharge was nearly maximum ( $52 \mathrm{~L} \mathrm{~s}^{-1}$ ) during the flood experiment, while at GB the maximum of $66 \mathrm{~L} \mathrm{~s}^{-1}$ occurred naturally, 12 days before the experiment (Table 1). In GB, within a few days after the flow pulse, discharge decreased (31 $\mathrm{L} \mathrm{s}^{-1}$ ) (Fig. 2). During the post-flow pulse period, discharge significantly decreased with time at all three study sites $(r>-0.88, p<0.01)$. Mean water temperature was highest in the more exposed site, GB $\left(16.6{ }^{\circ} \mathrm{C}\right)$, than in $\mathrm{T} 4\left(14.8^{\circ} \mathrm{C}\right)$ and was lowest at $\mathrm{T} 5$, with a more dense riparian canopy $\left(13.8^{\circ} \mathrm{C}\right)$.

The changes in flow between dates (Fig. 3 ) indicated that discharge oscillations at T5 and T4 followed the same trend, while GB showed a gradual decrease. This shows that during wet years, such as in this study, direct runoff from T4 tends to determine flow at the downstream $\mathrm{T} 5$ section. Flow change calculated at the sites from previous years with lower discharges (2000-2001) indicated the same trend for GB and T5, where nearby groundwater springs drive similar flow dynamic at both sites (Fig. 3).

The grain size composition of the streambed at T5 and GB were nearly similar, with 55-62\% coarse material (bedrock and cobbles) and $37-43 \%$ fine grain-size (gravel, sand and silt) (Table 1). The streambed in T4 mainly consisted of coarse particles (85\%).

Nitrate contents were significantly higher at GB and T5 than at T4, while phosphates, DOC and silica had similar values at all three sites. Nitrate values decreased from the beginning of the experiment towards the end at all sites (GB from 2.99 to $0.92 \mathrm{mg} \mathrm{N} / \mathrm{L}$; T4 from 1.03 to $0.32 \mathrm{mg} \mathrm{N} / \mathrm{L}$; T5 from 2.09 to $1.16 \mathrm{mg} \mathrm{N} / \mathrm{L}$ ), while DOC followed the opposite trend (GB from 2.85 to $4.38 \mathrm{mg} \mathrm{L}^{-1}$; $\mathrm{T} 4$ from 4.71 to $5.78 \mathrm{mg} \mathrm{L}^{-1}$; T5 from 3.61 to $4.54 \mathrm{mg} \mathrm{L}^{-1}$ ).

There were no differences in the environmental variables measured at the Surber's positions (e.g. water depth, velocity and substrate composition) on the previous date (March 17, 2006) to the simulated flow pulses among all site reaches (U Mann-Whitney test; $p>0.05$; Table S2).

\subsection{Characteristics of resources and benthic invertebrate assemblages}

Chlorophyll $a$, AFDM, CBPOM, FBPOM and total BPOM differed among sites (Table 1). Chlorophyll $a$ and AFDM were higher at GB than at T5 and T4, showing lowest values at T4. CBPOM, FBPOM stocks were also higher at GB and T5 than at T4, this last site again with lowest stocks.

A total of 45 taxa accounting for 9800 individuals were collected (Surbers, $n=249$ ). Baetis sp., Orthocladiinae and Tanypodinae were the most common and abundant taxa in all three sites, while Simulidae was also abundant in T5 and T4, and Echinogammarus monomerus only in GB. The nMDS produced a 2-axis ordination with a final stress value of 0.25 (Fig. S1), which indicates a satisfactory solution (stress values $>2$ indicate unreliable and poor solutions; Clarke, 1993). ANOSIM analysis indicated significant differences in taxa composition among the three sites (Global- $R=0.194, p<0.001$, ANOSIM). Even though most taxa were common at all sites, GB had slightly higher taxonomic richness, with nine exclusive taxa versus three in T5, and two in T4. 
Table 1

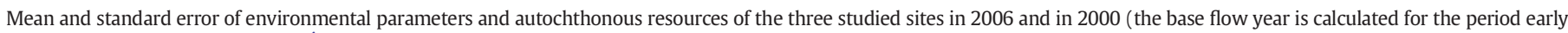
November 2000 to mid-July 2001 (Álvarez and Pardo, 2007)). Abbreviations in table are explained in the methods section.

\begin{tabular}{|c|c|c|c|c|c|c|c|}
\hline & & GB 2006 & GB 2000 & T4 2006 & T4 2000 & T5 2006 & T5 2000 \\
\hline \multirow[t]{2}{*}{ Periphyton } & $\operatorname{AFDM}\left(\mathrm{g} \mathrm{m}^{-2}\right)$ & $3.7 \pm 0.21^{* *}$ & $8 \pm 1.2$ & $1.39 \pm 0.09^{* *}$ & $16.2 \pm 1.7$ & $2.28 \pm 0.17^{* *}$ & $37.6 \pm 3.5$ \\
\hline & Chl a $\left(\mathrm{mg} \mathrm{m}^{-2}\right)$ & $0.077 \pm 0.007^{* *}$ & $17.4 \pm 2.9$ & $0.014 \pm 0.001^{* *}$ & $25.4 \pm 4.2$ & $0.03 \pm 0.003^{* *}$ & $111.8 \pm 9.7$ \\
\hline \multirow[t]{2}{*}{ Bentic organic material } & CBPOM $\left(\mathrm{g} \mathrm{m}^{-2}\right)$ & $10.23 \pm 1.66^{*}$ & $159.5 \pm 31.6$ & $6.19 \pm 1.42^{*}$ & - & $9.84 \pm 2.23^{*}$ & - \\
\hline & FBPOM $\left(\mathrm{g} \mathrm{m}^{-2}\right)$ & $2.03 \pm 0.43^{* *}$ & $13.7 \pm 2.1$ & $0.87 \pm 0.15^{* *}$ & - & $1.19 \pm 0.31^{* *}$ & - \\
\hline Hydromorphological & Basin area $\left(\mathrm{km}^{2}\right)$ & 3.9 & & 3.4 & & 7.7 & \\
\hline \multirow[t]{8}{*}{ Variables } & Channel width (m) & $4.7 \pm 0.1$ & $0.9 \pm 0.0$ & $3.4 \pm 0.1$ & $1.33 \pm 0.1$ & $3.5 \pm 0.1$ & $2.0 \pm 0.1$ \\
\hline & Slope & 0.0246 & & 0.0201 & & 0.0236 & \\
\hline & Discharge $\left(\mathrm{L} \mathrm{s}^{-1}\right)$ & $25.5 \pm 6.5$ & $8.9 \pm 2.4$ & $35.0 \pm 8.1$ & $3.3 \pm 1.2$ & $46.3 \pm 5.3$ & $13.3 \pm 5.1$ \\
\hline & Max. discharge $\left(\mathrm{L} \mathrm{s}^{-1}\right)$ & 65.9 & 31.75 & 53.6 & 16.85 & 75.9 & 69.9 \\
\hline & Mean $\Omega\left(\mathrm{W} \mathrm{m}^{-2}\right)$ & $6.1 \pm 1.6$ & - & $8.1 \pm 1.6$ & - & $9.1 \pm 1.2$ & - \\
\hline & $\operatorname{Max} \Omega\left(\mathrm{W} \mathrm{m}^{-2}\right)$ & 15.9 & - & 12.4 & - & 14.9 & - \\
\hline & $\%$ coarse substrata & $62.1 \pm 4.2$ & $12.8 \pm 2.8$ & $85.2 \pm 3.2$ & $49.5 \pm 4.0$ & $55.2 \pm 4.5$ & $70.6 \pm 4.1$ \\
\hline & \% fine substrata & $37.9 \pm 4.2$ & $44.3 \pm 2.9$ & $14.8 \pm 3.2$ & $39.7 \pm 3.0$ & $43.5 \pm 4.5$ & $19 \pm 2.1$ \\
\hline \multirow[t]{8}{*}{ Physico-chemical } & Water temp. ${ }^{\circ} \mathrm{C}$ & $17.7 \pm 1.4^{*}$ & $16.9 \pm 1.2$ & $15.6 \pm 0.5$ & $18.3 \pm 1.7$ & $14.4 \pm 0.5$ & $13.8 \pm 1.0$ \\
\hline & $\mathrm{O}_{2} \mathrm{mg} \mathrm{L}^{-1}$ & 9.8 & $9.2 \pm 0.4$ & 9.6 & $9.6 \pm 0.2$ & 10.0 & $10.2 \pm 0.3$ \\
\hline & $\mathrm{pH}$ & 8.1 & $7.4 \pm 0.1$ & 8.5 & $7.6 \pm 0.1$ & 8.3 & $7.9 \pm 0.1$ \\
\hline & Conductivity $\left(\mu \mathrm{S} \mathrm{cm}^{-1}\right)$ & $737.2 \pm 25.3$ & $763.2 \pm 44.1$ & $638.4 \pm 42.8$ & $1104.9 \pm 108.6$ & $664.6 \pm 29.2$ & $709.4 \pm 33.8$ \\
\hline & $\mathrm{N}-\mathrm{NO}_{3}^{-}\left(\mathrm{mg} \mathrm{L}^{-1}\right)$ & $1.39 \pm 0.20^{* *}$ & & $0.52 \pm 0.7$ & & $1.17 \pm 0.12$ & \\
\hline & $\mathrm{P}-\mathrm{PO}_{4}^{3-}\left(\mathrm{mg} \mathrm{L}^{-1}\right)$ & $0.04 \pm 0.01$ & & $0.02 \pm 0.01$ & & $0.03 \pm 0.01$ & \\
\hline & $\mathrm{DOC}\left(\mathrm{mg} \mathrm{L}^{-1}\right)$ & $4.44 \pm 0.50$ & & $4.73 \pm 0.37$ & & $4.13 \pm 0.25$ & \\
\hline & $\mathrm{SiO}_{2}\left(\mathrm{mg} \mathrm{L}^{-1}\right)$ & $3.02 \pm 0.32$ & & $2.69 \pm 0.25$ & & $2.90 \pm 0.41$ & \\
\hline \multirow[t]{3}{*}{ Hyporheos } & Water Temp. ${ }^{\circ} \mathrm{C}$ & 17.8 & & 19.2 & & 17.1 & \\
\hline & $\mathrm{O}_{2} \%$ & 93.3 & & 89.7 & & 96.1 & \\
\hline & Conductivity $\left(\mu \mathrm{sm}^{-1}\right)$ & 784.7 & & 795.0 & & 788.0 & \\
\hline
\end{tabular}

${ }^{*}$ Kruskal-Wallis Test, significance difference between sites ${ }^{* *} p<0.001,{ }^{*} p<0.05$.

A total of 22 taxa accounting for 1331 individuals were collected in the hyporheic zone of the three study sites. Mean invertebrate density was 8 in. $\mathrm{L}^{-1}$ (ranging from 1 to 17 in. $\mathrm{L}^{-1}$ ) and mean taxa richness was 8 (ranging from 4 to 15 taxa). Non-metric multidimensional scaling (Fig. S1) and ANOSIM analysis (Global- $R=-0.05, p=0.6$ ) demonstrated that there were no differences between the hyporheic invertebrate assemblages among the three sites. In general, assemblages in the three sites were dominated by dipterans (e.g. Chironominae, Orthocladinae, Corynoneura sp. and Tanypodinae) and Oligochaeta, which together represented $>90 \%$ of the hyporheos. The hyporheic taxa were mainly characterized as being small-size organisms (1-5 cm); with short lifecycles (one year or less); having one or more generations per year; having passive aquatic dispersal; showing diapause or dormancy, and non-resistance form; tegument and gills respiration; feeding living microphytes, detritus and living invertebrates; deposit feeders, scrapers, predators; swimmers and crawlers (Fig. S3).

Indicator species analysis revealed significant differences in biological traits between invertebrates inhabiting the hyporheic and benthic zones. Hyporheic taxa were associated with small organisms, cocoons as a resistance form, and feeding of microorganisms which are within the fine sediments, whereas benthic taxa were associated with aerial respiration (by spiracles), being piercers and feeding on vertebrates (Table 2).

\subsection{Resistance of resources and benthic invertebrates to an experimental flow pulse}

Resources (Chl $a$, AFDM, CBPOM and FBPOM) and benthic invertebrates (richness, density and drift) were not significantly affected by the flow pulse (Wilcoxon test; Table 3). However, drift rates showed an increase due to the flow pulse (Table 3). For example, mean drift rate at GB was 2 in. $\mathrm{m}^{-3}$ in the control reach and 56 in. $\mathrm{m}^{-3}$ in the disturbed reach during the flow pulse (Table 3). Ephemeroptera (Baetis rhodani) and Diptera (Orthocladiinae, Tanypodinae and Simulidae) accounted, on average, for $80 \%$ of drifting individuals at all three sites. Some taxa (e.g. Oligochaeta, Corynoneura sp., Thienemaniella sp., Ceratopogonidae and Dixa sp), only drifted during the flow pulse at GB. At T4, only 10 taxa drifted during the flood (e.g. Oligochaeta, E. monomerus, Corynoneura sp. and Hydroptila sp.). In spite of the fact that drift at the
T5 control reach was almost zero, the flow pulse increased the number of drifting individuals $>8$ times (e.g. E. monomerus, Tyrrhenoleuctra antoninoi, Dicranota sp. and Dixa sp.).

\subsection{Resilience of resources and benthic invertebrates to the flow pulse}

Taxa richness and density at the $\mathrm{T} 5$ control reach did not vary significantly between the $2 \mathrm{~h}$ after and the three days after samples, the last samples taken posterior to flow pulse manipulation at upstream reaches (Wilcoxon test). These results point to the absence of impact on community structure from flow pulses driven at upstream reaches over the downstream T5 control reach.

Considering resources, PRC analyses did not evidence differences in BPOM fractions and Chl $a$ between control and flood reaches at the sites (PRC analysis; GB: $\mathrm{F}=1.5, p=0.99 ; \mathrm{T} 4: \mathrm{F}=0.6, p=0.98$; T5: $\mathrm{F}=0.01, p=0.95)$. In addition, T4 and T5 did not experience changes in taxonomic composition between control and flooded reaches through time (PRC; Fig. S2). In contrast, significant differences were observed in $\mathrm{GB}$ (Monte Carlo permutation test $\mathrm{F}=11.6, p<0.05$; Fig. 4). In particular, Echinogammarus monomerus and Thienemanniella sp. decreased markedly in response to flooding in GB (Fig. 4). For example, 35 days after the experiment, the density of E. monomerus was reduced by $20 \%$ and Thienemanniella sp. by $37 \%$. Also some dipterans (e.g. Corynoneura sp., Orthocladinae and Tanypodinae) and Baetis rhodani were negatively affected. However, Chironominae was the most positively (16\% increase) affected taxon, which indicates either a quick recovery or colonization by new species. In spite of taxonomic changes observed at GB, PRCs performed on biological traits did not show significant changes at any stream reach.

\subsection{Temporal trends of resources and benthic invertebrates to receding flows}

Theil-Sen's linear regression was performed to test recovery trajectories along the studied period for BPOM sizes and periphyton variables, for control and flood reaches together and individually per site (Table 4). Coarse benthic particulate organic matter increased along the whole studied period at all sites $(p<0.001)$, while FBPOM increased only at GB $(p<0.001)$. Chlorophyll $a$ only showed a significant 
Density

T5

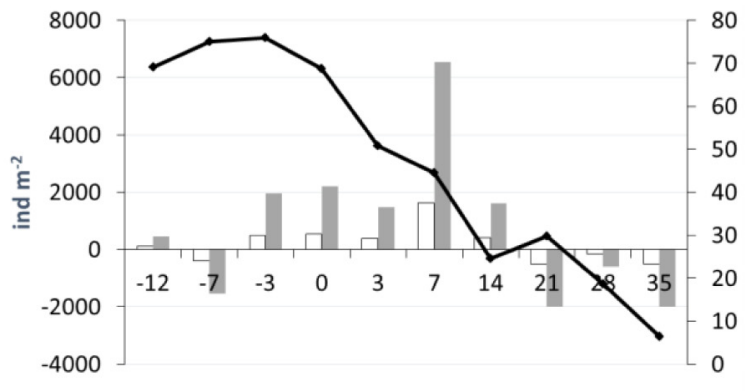

T4

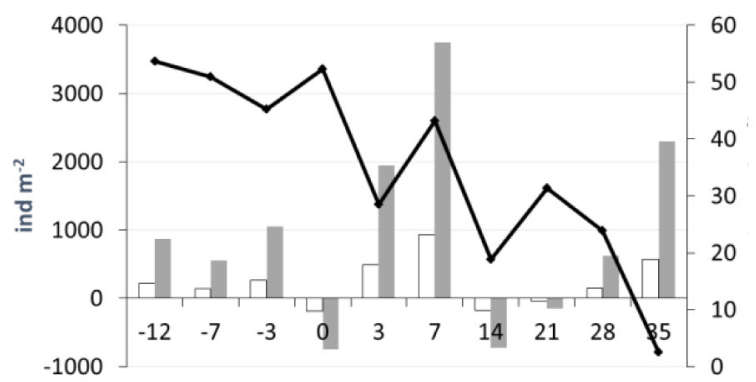

Richness

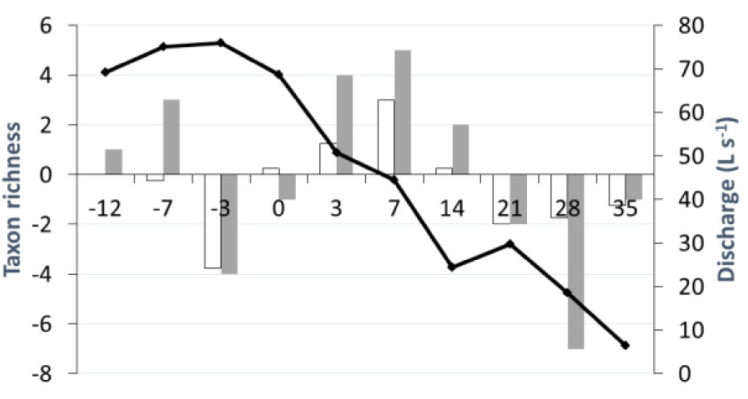

$\square$ Mean - Total $\rightarrow$ Discharge

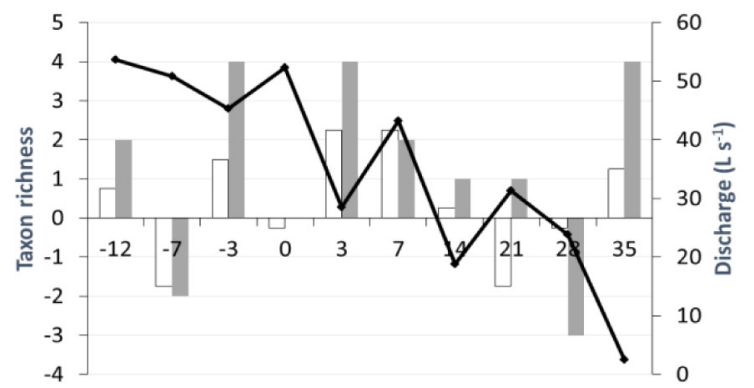

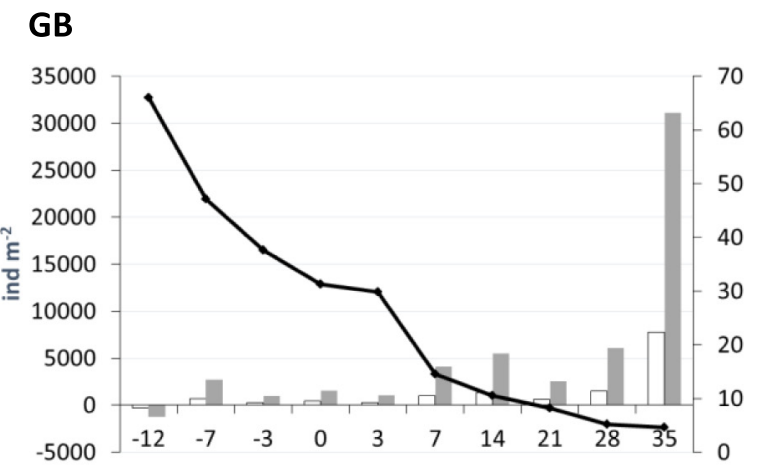

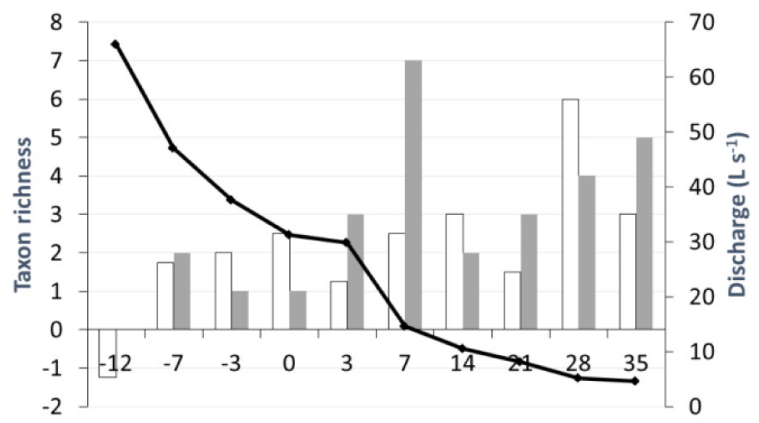

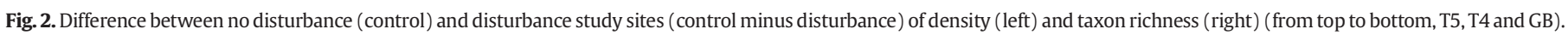

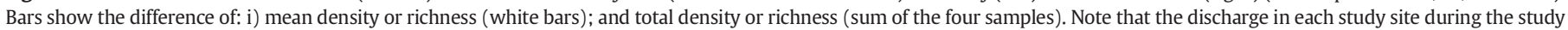
period is represented by the black line.
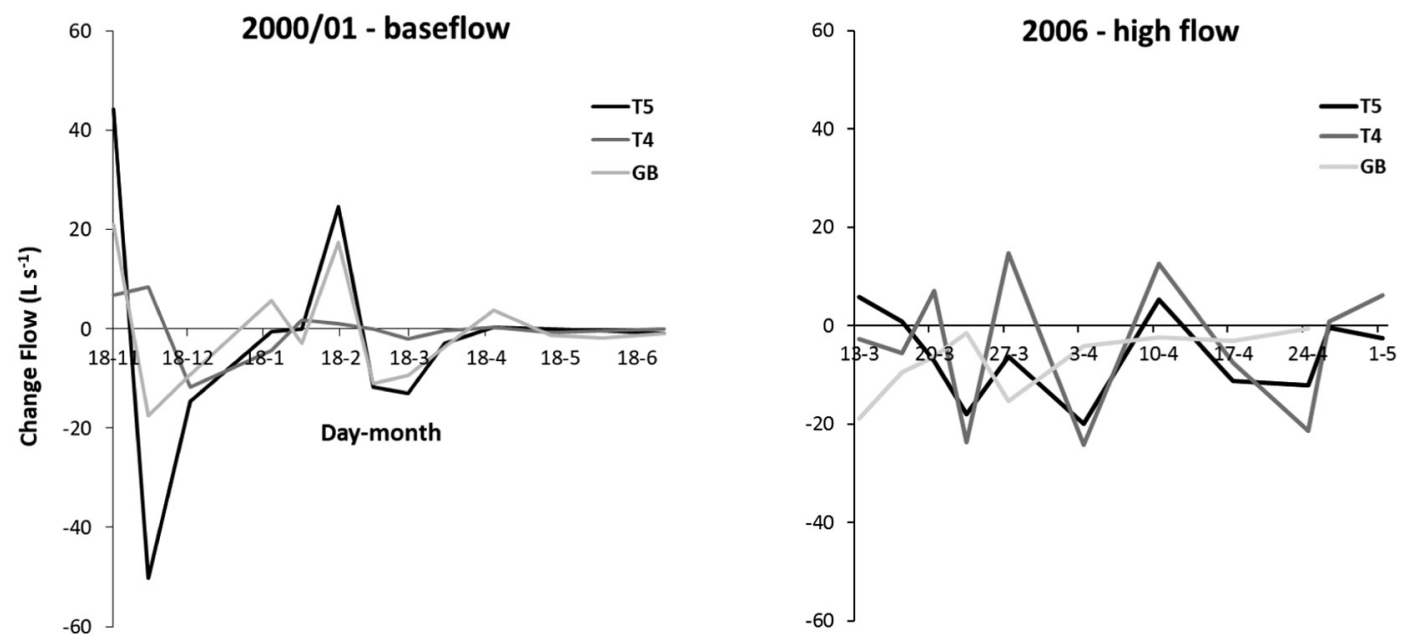

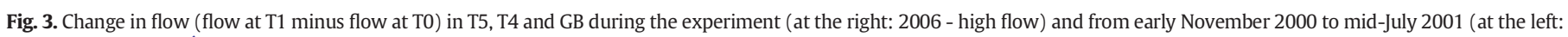
2000/01 - baseflow; Álvarez and Pardo, 2007). 
Table 2

Statistically significant indicator trait categories for hyporheic and benthic macroinvertebrates in the Ternelles stream. (IV = Indicator Values). Significance indicator between hyporheic and benthic zone ${ }^{* *}<0.001,{ }^{*}<0.05$.

\begin{tabular}{lll}
\hline & Trait category & IV \\
\hline Hyporheic zone & Maximal size: $\leq 0.25 \mathrm{~cm}$ & $0.89^{* *}$ \\
& Maximal size: $>8 \mathrm{~cm}$ & $0.88^{* *}$ \\
& Resistance forms: cocoons & $0.87^{* *}$ \\
& Food: fine sediment + microorganisms & $0.86^{*}$ \\
Benthic zone & Respiration: spiracle(aerial) & $0.97^{* *}$ \\
& Feeding habits: piercer (plant or animal) & $0.91^{* *}$ \\
& Food: vertebrates & $0.82^{*}$ \\
\hline
\end{tabular}

decreasing tendency along time at T5 $(p<0.001)$, and AFDM followed the opposite increasing trajectory at T5 $(p<0.001)$ and GB $(p<0.01)$.

Taking into account that PCR results only identified significant taxonomic composition changes between control and flooded reaches at GB, control and flooded reaches at this site were analyzed independently. T4 and T5 showed similar composition at control and flooded reaches through time, and control and flooded replicates were therefore merged. Richness and density of benthic invertebrates increased with time at T5 and in control reaches at GB (linear regressions; $p<0.05$ ), and not significantly at T4 and in GB flooded reaches (Table 5; Fig. 2). Densities in control reaches at the end of the study were one order of magnitude higher at GB $\left(41,924\right.$ in. $\left.\mathrm{m}^{-2}\right)$ than at T4 $\left(5225 \mathrm{in.} \mathrm{m}^{-2}\right)$ and T5 (4475 in. $\mathrm{m}^{-2}$ ).

Regarding biological traits, Table 6 shows a number of trait changes during the two-month study, characterized by decreasing discharges. For example: i) an increase of taxa with a life cycle duration longer than one year (T5 and GB), shredder (T5), and surface swimmers (T5 and T4), and ii) a decrease of taxa breathing through gills (T5), feeding on plant detritus (T5) and feeding on living microinvertebrates (predators T4), having aerial passive dispersal (GB) and being burrowers (T5, T4 and GB).

\subsection{Hyporheos contribution to benthic invertebrate composition under receding flows}

Linear regressions were performed to explore the relationship between the superficial benthic and hyporheic invertebrate richness with receding discharge values, which may help to discern if benthos colonizers originate from the hyporheos (Fig. 5). Taxa richness in the benthic zone (BenTot) and the number of taxa observed only in the benthic zone (Ben) (not present in the hyporheos) increased as discharge decreased at T5 (Fig. 5). The number of common taxa present in the hyporheic zone and in the benthic zone (Both) increased as discharge reduced at both $\mathrm{T} 5$ and $\mathrm{GB}$. This indicates that a decrease in discharge produced an increase of the number of hyporheic taxa in the benthic zone, while the opposite tendency was observed for only hyporheic taxa (Hyp) at T5 and GB, with few hyporheic taxa not present in the benthos following discharge reduction. No significant relationship was observed between benthic and hyporheic taxa composition and discharge at $\mathrm{T} 4$.

\section{Discussion}

High flows have many effects on aquatic invertebrates, both directly and indirectly, through changes to habitat (Death, 2008). This study demonstrates that results from small-scale experimental flow pulses seem to be influenced by previous levels of high flow disturbance. The first prediction of flow pulses depleting the streambed of resources and invertebrates, low resistance, was only partially confirmed for the more stable-in-flow site (i.e. invertebrate composition at GB). Second, recovery at the disturbed sites was slow (low resilience), because in spite of high connectivity at high flows, the whole stream system was disturbed, contrary to what was expected, influencing low resource stocks and fewer invertebrate richness and densities. These results confirm that the greater scale of previous disturbance levels (at the whole stream scale) strongly influenced the rate and pathways of recolonization and the sources and faunal composition of the recolonists (Brooks and Boulton, 1991). Third, it was predicted that there would be a gradual shift in trait representation from flood-resistant traits after the flow pulses to drought-resistant traits with decreasing flows towards summer. The results confirmed this for a number of related traits.

\subsection{Resistance and resilience of resources and benthic invertebrates (rich- ness, density and drift) to an experimental flow pulse}

The flow pulses did not influence resources and benthic invertebrates (richness, density and drift) at the studied sites. However, differences in invertebrate composition were observed at GB. The recovery of the community at the GB control reach became evident at the end of the experiment (two months). Exponential increases in grazers (Baetis sp. and Orthocladiinae) and early leaf colonizers as Corynoneura sp. (García et al., 2012) were observed, coupled with increasing amounts of CPBOM, FPBOM and AFDM at the site. At the GB flooded reach, community recovery was less evident, with lower increases in density. The absence of increases in Chl $a$ can only be attributed to herbivory, as demonstrated in a previous study at this site (Álvarez and Pardo, 2009), and in this experiment, similar patterns of increases in herbivores coupled with reductions in Chl $a$ at both control and flooded reaches were observed. There is evidenced that the recruitment of new colonizers seems negatively influenced by the low resilience of allochthonous organic matter stocks and by a high top-down consumption of benthic Chl $a$.

Although invertebrate composition was altered by the flow pulse in $\mathrm{GB}$, biological traits did not change. This was attributed to the previous

Table 3

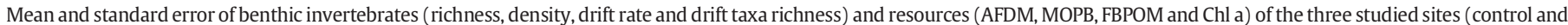
flooding reach) for the period before (three days before) and after ( $2 \mathrm{~h}$ after) the flow pulse.

\begin{tabular}{|c|c|c|c|c|c|c|c|c|c|c|}
\hline Site & Reach & Period & Richness & $\begin{array}{l}\text { Density } \\
\left(\text { ind } \mathrm{m}^{-2} \text { ) }\right.\end{array}$ & $\begin{array}{l}\text { Drift rate } \\
\text { (ind } \mathrm{m}^{-3} \text { ) }\end{array}$ & $\begin{array}{l}\text { Drift taxa richness } \\
\left(\text { taxon } \mathrm{m}^{-3}\right)\end{array}$ & $\begin{array}{l}\text { AFDM } \\
\left(\mathrm{g} \mathrm{m}^{-2}\right)\end{array}$ & $\begin{array}{l}\text { MOPB } \\
\left(\mathrm{g} \mathrm{m}^{-2}\right)\end{array}$ & $\begin{array}{l}\text { FBPOM } \\
\left(\mathrm{g} \mathrm{m}^{-2}\right)\end{array}$ & $\begin{array}{l}\text { Chl a } \\
\left(\mathrm{mg} \mathrm{m}^{-2}\right)\end{array}$ \\
\hline \multirow[t]{4}{*}{ T5 } & \multirow[t]{2}{*}{ Control } & Before & $3.2 \pm 0.2$ & $1450.0 \pm 1250.2$ & \multirow[t]{2}{*}{$5.0 \pm 0.4$} & \multirow[t]{2}{*}{$0.6 \pm 0.1$} & $1.4 \pm 0.2$ & $0.9 \pm 0.8$ & $0.03 \pm 0.02$ & $0.02 \pm 0.01$ \\
\hline & & After & $5.2 \pm 0.6$ & $843.5 \pm 288.4$ & & & $3.1 \pm 0.8$ & $0.02 \pm 0.02$ & $0.01 \pm 0.00$ & $0.05 \pm 0.02$ \\
\hline & \multirow[t]{2}{*}{ Flooding } & Before & $7.0 \pm 1.1$ & $962.5 \pm 456.7$ & \multirow[t]{2}{*}{$41.9 \pm 10.8$} & \multirow[t]{2}{*}{$3.5 \pm 0.8$} & $141.7 \pm 56.1$ & $0.04 \pm 0.04$ & $0.02 \pm 0.01$ & $0.06 \pm 0.02$ \\
\hline & & After & $5.0 \pm 1.5$ & $293.7 \pm 65.6$ & & & $2.8 \pm 1.0$ & $1.9 \pm 0.8$ & $0.3 \pm 0.1$ & $0.05 \pm 0.01$ \\
\hline \multirow[t]{4}{*}{$\mathrm{T} 4$} & \multirow[t]{2}{*}{ Control } & Before & $6.0 \pm 1.3$ & $1006.2 \pm 245.2$ & \multirow[t]{2}{*}{$28.3 \pm 8.9$} & \multirow[t]{2}{*}{$4.3 \pm 1.4$} & $1.6 \pm 0.4$ & $0.2 \pm 0.2$ & $0.1 \pm 0.0$ & $0.02 \pm 0.01$ \\
\hline & & After & $5.2 \pm 1.3$ & $312.5 \pm 41.4$ & & & $2.2 \pm 0.7$ & $0.2 \pm 0.2$ & $0.04 \pm 0.03$ & $0.02 \pm 0.01$ \\
\hline & \multirow[t]{2}{*}{ Flooding } & Before & $4.5 \pm 0.9$ & $743.7 \pm 227.4$ & \multirow[t]{2}{*}{$41.4 \pm 7.8$} & \multirow[t]{2}{*}{$9.2 \pm 2.4$} & $1.0 \pm 0.1$ & $0.1 \pm 0.1$ & $0.03 \pm 0.02$ & $0.005 \pm 0.001$ \\
\hline & & After & $5.5 \pm 1.9$ & $500 \pm 255.8$ & & & $2.3 \pm 0.3$ & $0.1 \pm 0.0$ & $0.01 \pm 0.01$ & $0.01 \pm 0.006$ \\
\hline \multirow[t]{4}{*}{ GB } & \multirow[t]{2}{*}{ Control } & Before & $12.2 \pm 1.0$ & $1500 \pm 281.7$ & \multirow[t]{2}{*}{$20.7 \pm 2.7$} & \multirow[t]{2}{*}{$5.2 \pm 0.7$} & $7.1 \pm 3.1$ & $0.8 \pm 0.4$ & $0.1 \pm 0.1$ & $0.2 \pm 0.1$ \\
\hline & & After & $7.0 \pm 1.1$ & $606.2 \pm 158.6$ & & & $2.6 \pm 0.4$ & $0.2 \pm 0.2$ & $0.03 \pm 0.01$ & $0.03 \pm 0.01$ \\
\hline & \multirow[t]{2}{*}{ Flooding } & Before & $10.2 \pm 2.5$ & $1256.2 \pm 197.2$ & \multirow[t]{2}{*}{$56.1 \pm 7.1$} & \multirow[t]{2}{*}{$10.2 \pm 2.6$} & $4.8 \pm 1.0$ & $0.5 \pm 0.1$ & $0.06 \pm 0.02$ & $0.1 \pm 0.02$ \\
\hline & & After & $4.5 \pm 0.5$ & $212.5 \pm 51.5$ & & & $3.7 \pm 0.6$ & $0.4 \pm 0.1$ & $0.04 \pm 0.02$ & $0.1 \pm 0.03$ \\
\hline
\end{tabular}




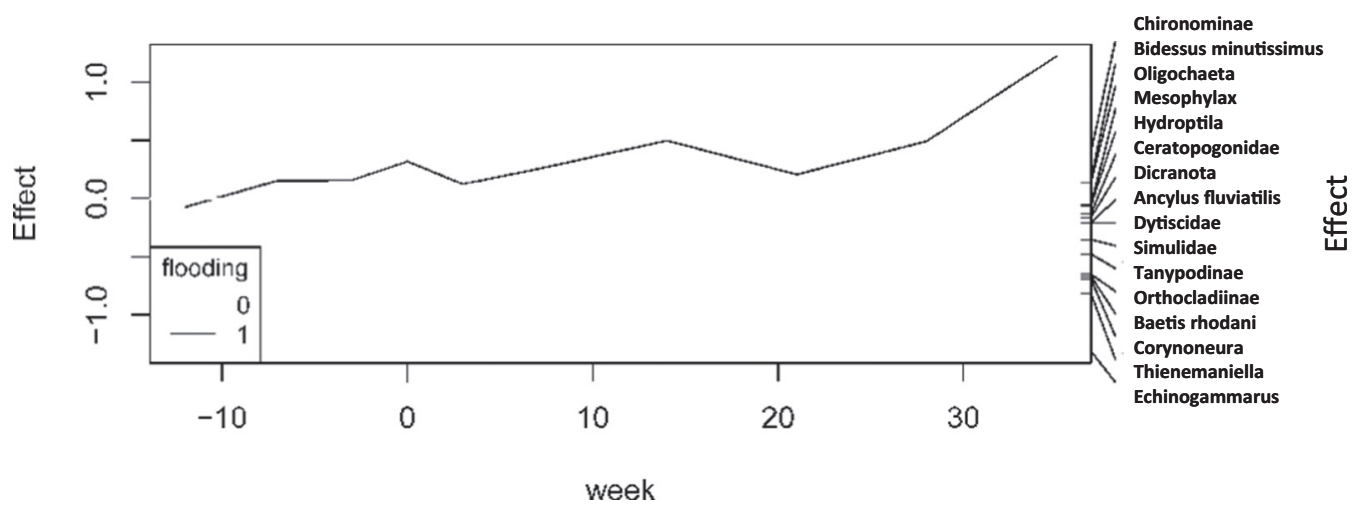

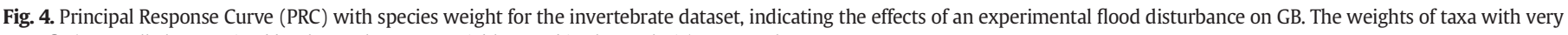
poor fit (not well characterized by the explanatory variables used in the analysis) are not shown.

winter spates that had already selected among those more resistant traits, making species less likely to be killed or removed during the flow pulse disturbance (Townsend et al., 1997). The lack of change in biological traits could also be due to a biased selection of traits related to a large-scale filter of life-cycle traits associated with climatic and environmental characteristics of intermittent rivers instead of traits directly related to floods (Bonada et al., 2007; Lobera et al., 2017). In fact, Lobera et al. (2019) showed that invertebrates in temporary streams of Mallorca possessed the life strategy traits to adapt and survive seasonal and supra-seasonal drying events (e.g. small sizes, multivoltine life-cycles and aerial respiration). Overall, if initially designed, the flood manipulation should have coincided with the receding base flow discharge, and the experimental floods should probably have more severely affected the invertebrate composition and their corresponding biological traits.

Increasing drift rates during the simulated flow pulse were observed accordingly with discharge, while changes were not significant, probably because the high between-samples variability. It is well known that abiotic and biotic factors influence active drift (which is initiated by the organism), while only abiotic factors influence passive drift (which is a result of a change in the physical conditions) (Brittain and Eikeland, 1988; Kobak et al., 2017). Active drift at controls was mainly composed of swimmer and crawler invertebrates (e.g. Baetis rhodani, Orthocladiinae, Tanypodinae and Simulidae); taxa also identified in other drift studies (Malmqvist and Sjöström, 1987; Winterbottom et al., 1997; Naman et al., 2016). Other species entered drift because of the flood manipulation, only because of their susceptibility to flow perturbation (e.g. Oligochaeta, Corynoneura sp., Thienemaniella sp., Ceratopogonidae, Dixa sp. and Echinogammarus monomerus). The simulated flow pulse, considered as a medium flood for the grain-sizes entrained, did not produce a catastrophic drift, as the invertebrate community was not fully mobilized.

\subsection{Temporal trends of resources and benthic invertebrates to receding flows}

Results evidenced that winter discharges were large enough to mobilize the bed sediment, scouring most of the benthic algae (Gerull et al.,

Table 4

Theil-Sen's slope values of resources $\left({ }^{* * *}=\mathrm{p}<0.001\right.$; $\left.^{* *}=\mathrm{p}<0.01\right)$.

\begin{tabular}{llllc}
\hline & CBPOM & FBPOM & Chl $a$ & AFDM \\
\hline GB & $0.1593^{* * *}$ & $0.0179^{* * *}$ & 0.0000 & $0.0179^{* *}$ \\
T4 & $0.0604^{* * *}$ & 0.0000 & 0.0000 & -0.0046 \\
T5 & $0.0508^{* * *}$ & 0.0000 & $-0.0003^{* * *}$ & $0.0108^{* * *}$
\end{tabular}

2012; Katz et al., 2017), controlling the spatial patterns of periphyton biomass and resetting the succession of stream periphyton communities (Fisher et al., 1982; Biggs et al., 1999). In addition to initially very low standing stocks of this study, post-flood trajectories showed further reduction in benthic $\mathrm{Chl} a$, with discharge reduction contrary to that expected. In the unshaded conditions of the study sites, low ambient nutrient levels should affect periphyton biomass most (bottom-up control) as in many unpolluted, permanent headwaters (Lowe et al., 1986) with P and $\mathrm{N}$ as limiting factors (Grimm and Fisher, 1986). However, nutrient levels were similar or higher than values measured in a previous studied year in Ternelles when periphyton biomass was much higher (Álvarez and Pardo, 2007).

Riparian areas in the basin are dominated by Holm oak (Quercus ilex), a Mediterranean evergreen species having litter fall between April and July (Bussotti et al., 2003; Cherbuy et al., 2001). Initial benthic POM stocks in March were much lower than previous studies in GB (Álvarez and Pardo, 2007), probably because winter floods reduced litter retention and accumulation. Meanwhile, in the post-flood period, CBPOM increased as expected, showing slow recovery without reaching values of a typical year. Because Holm oak decomposing time is long, a half-time of about four months in streams (Schwarz and Schwoerbe, 1997), leaves that fall in the stream during March-April will not be fully decomposed in June-July when the stream channels may dry. In an earlier study, litter accumulation in GB was related to shredders density showing an increasing tendency towards summer (Pardo and Álvarez, 2006; Álvarez and Pardo, 2009).

Regarding benthic invertebrates, fewer taxa richness and density at the beginning of the experiment was found than in a previous study, when base flow conditions prevailed (mean richness from 31 to 15 , and mean densities from 10,500 to 3700 in. $\mathrm{m}^{-2}$ ). Over time, the flow decreased in the Ternelles stream, and the ecosystem turned into the yearly based period of flow cessation or disconnected pools. Although taxa richness and density increased, they did not reach the values attained in previous studied years. Some biological traits increased, associated with survival during the dry phases of those which could

\section{Table 5}

Linear regression model results with time, and taxa richness and density as dependent variable.

\begin{tabular}{|c|c|c|c|c|c|}
\hline \multirow[t]{2}{*}{ Site } & & \multicolumn{2}{|c|}{ Richness } & \multicolumn{2}{|c|}{ Density (Ind $\mathrm{m}^{-2}$ ) } \\
\hline & & $p$ & $\mathrm{R}^{2}$ & $p$ & $\mathrm{R}^{2}$ \\
\hline \multirow[t]{2}{*}{ GB } & Control & 0.000 & 0.31 & 0.000 & 0.39 \\
\hline & Flooded & 0.064 & 0.06 & 0.107 & 0.07 \\
\hline $\mathrm{T} 4$ & Control + flooded & 2.093 & 0.05 & 0.581 & 0.04 \\
\hline $\mathrm{T} 5$ & Control + flooded & 0.000 & 0.22 & 0.002 & 0.12 \\
\hline
\end{tabular}


Table 6

Linear regression model results with discharge and relative trait occurrence (presence/absence data) as dependent variable. Only significant results are shown.

\begin{tabular}{|c|c|c|c|c|}
\hline Trait category & Trait class & $p$ & $\mathrm{~F}$ & $\mathrm{R}^{2}$ \\
\hline \multicolumn{5}{|l|}{ T5 } \\
\hline Life cycle duration & $>1$ year & 0.029 & 7.061 & -0.469 \\
\hline $\begin{array}{l}\text { Number of life cycles per } \\
\text { year }\end{array}$ & Univoltine & 0.031 & 6.794 & 0.459 \\
\hline Respiration & Gills & 0.047 & 5.515 & 0.408 \\
\hline Food & Plant detritus $\geq 1 \mathrm{~mm}$ & 0.042 & 5.829 & 0.421 \\
\hline Feeding habits & Shredder & 0.031 & 6.801 & -0.460 \\
\hline Locomotion & Surface swimmer & 0.023 & 7.825 & -0.494 \\
\hline Locomotion & Burrower (epibenthic) & 0.033 & 6.630 & 0.453 \\
\hline \multicolumn{5}{|l|}{$\mathrm{T} 4$} \\
\hline Maximal size & $4-8 \mathrm{~cm}$ & 0.027 & 7.293 & 0.477 \\
\hline Dispersal & Aquatic active & 0.023 & 7.884 & -0.496 \\
\hline Resistance form & None & 0.045 & 5.647 & 0.414 \\
\hline Respiration & Plastron & 0.021 & 8.128 & -0.504 \\
\hline Food & $\begin{array}{l}\text { Living } \\
\text { microinvertebrates }\end{array}$ & 0.000 & 39.224 & 0.831 \\
\hline Locomotion & Surface swimmer & 0.023 & 7.804 & -0.494 \\
\hline Locomotion & Burrower & 0.048 & 5.460 & 0.406 \\
\hline \multicolumn{5}{|l|}{ GB } \\
\hline Life cycle duration & $>1$ year & 0.011 & 10.987 & -0.579 \\
\hline Dispersal & Aerial passive & 0.005 & 14.62 & 0.646 \\
\hline Respiration & Spiracle (aerial) & 0.038 & 6.128 & -0.434 \\
\hline Feeding habits & Piercer & 0.043 & 5.769 & -0.419 \\
\hline Feeding habits & Parasite & 0.047 & 5.510 & 0.408 \\
\hline Locomotion & Flier & 0.041 & 5.937 & -0.426 \\
\hline Locomotion & Burrower & 0.009 & 11.923 & 0.598 \\
\hline Locomotion & Permanently attached & 0.001 & 29.549 & 0.787 \\
\hline
\end{tabular}

migrate to the hyporheic zone (e.g. burrower locomotion, gill respiration and microinvertebrates feeding). However, some other traits decreased, as shredding (associated with the flowing phases and BPOM accrual), aquatic active dispersal (associated with recolonization upstream to still flowing zones) or fliers (associated with recolonization of other different streams).

Inter-annual variability in rainfall (wet and dry years) drives differences in community composition and that may have lagged effects, with altered recruitment in one year affecting population densities in subsequent years (Resh et al., 2013). Precipitation in Mallorca showed a significant increasing autumn trend over the period 1977-2009 (Garcia et al., 2017), and this study demonstrated that this increasing tendency may lead to substantial reduction in the diversity of biological communities of temporary streams, reducing their resistance and resilience to flooding. Many organisms have mechanisms that allow them to adapt to summer droughts and to recover quickly after water returns in early autumn (Lake, 2003). However, the results indicate that high floods (spates) in autumn-winter strongly disturb resources and invertebrate communities, and repetition in spates do not provide sufficient time for full recovery of biological communities. High floods can even have such an impact that the communities do not recover before summer drought arrives, depending of course on the timing of the start of the drought period.

\subsection{Hyporheos contribution to benthic invertebrate under receding flows}

The hyporheic zone may provide an extensive refuge for hydrological disturbance in temporary rivers (Stubbington, 2012; Datry et al., 2016a). This study shows that approximately $50-60 \%$ of the benthic invertebrates were also present in the hyporheic zone. The invertebrate traits characterizing the benthos had spiracle (aerial) respiration, some being piercers of plants or animals, and some as food item vertebrates (Hirudinea, Nepa cinerea and Notonectidae). Biological traits of the hyporheic fauna of the study streams include active migration (swimmers and crawlers), tegument and gills respiration and small size, in concordance with other studies (Poff et al., 2006; Stubbington
T5

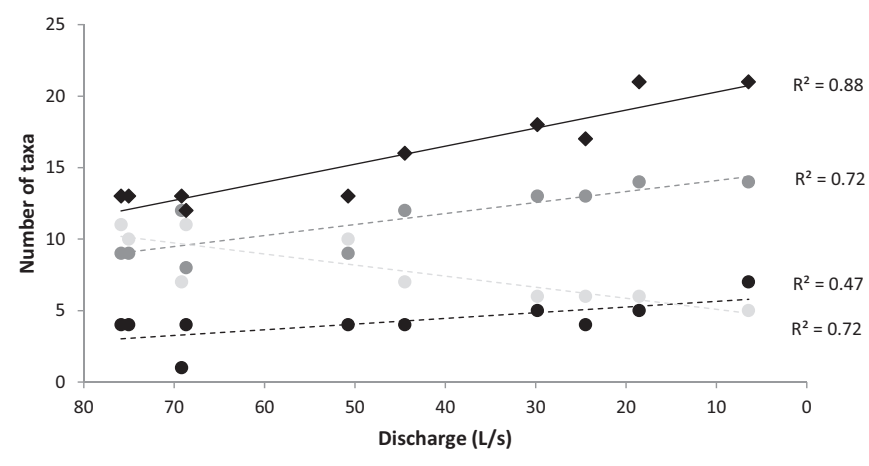

T4

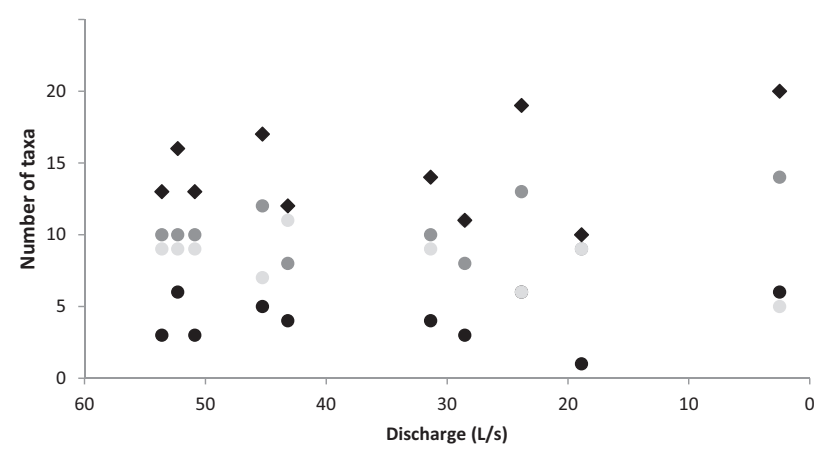

GB

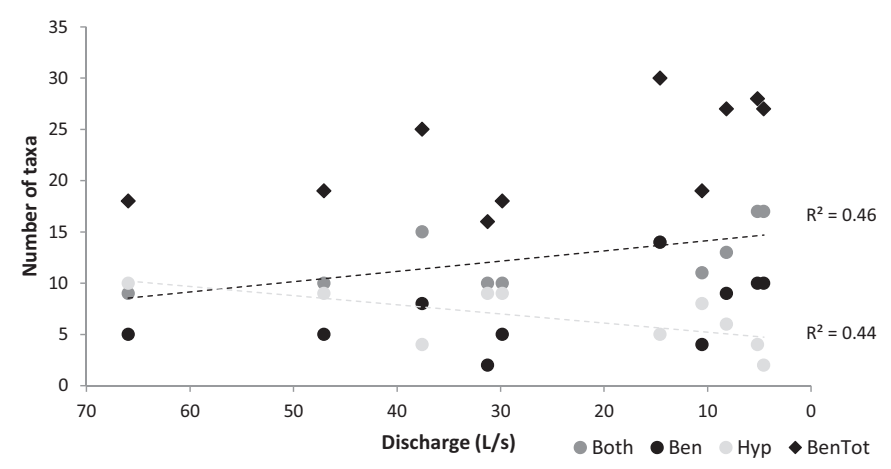

Fig. 5. Linear regression model with discharge and number of benthic and hyporheic invertebrates (BenTot: taxon richness in the benthic zone; both: number of common taxa observed in both the hyporheic and benthic zone; ben: number of taxa observed only in the benthic zone; and hyp: number of taxa observed only in the hyporheic zone but not in the benthic zone).

et al., 2017). These results indicate that the hyporheic zone was the main source of colonists as discharge decreased in GB and T5, but not in T4. These results could be related to higher discharge oscillations over time at $\mathrm{T} 4$ versus the progressive reduction of discharge observed over time in T5 and GB. It cannot be discounted that those taxa were transported by drift, despite the fact that $20-30 \%$ of the taxa found in the drift were also found in the hyporheos. As in other studies that found direct evidence of the hyporheic refuge hypothesis (Holomuzki and Biggs, 2007; Stubbington et al., 2011; Vander Vorste et al., 2016), the studied hyporheic zone contained taxa that seemed to move to the benthic zone during flow recession, indicating the important role of the hyporheic zone as a refuge for invertebrates escaping hydraulic alteration. Similar to this study, Durkota et al. (2019) found the existence of a more dynamic exchange between benthos and hyporheos during periods of low discharge. Moreover, a dominance of the trait "non-resistant form" in the community emphasizes that the hyporheic refuge may allow them to survive and persist over the summer period (Lobera et al., 2019). 


\section{Conclusions}

Results indicate that the simulated flow pulses applied at three sites within the Ternelles stream did not fully succeeded in depleting resources and altering invertebrate composition and traits, except for the change in community composition at GB. We believe that the absence of significant changes in resources and invertebrates was influenced by the previous higher-than-normal winter floods, which maintained the temporary streams at levels that can be characterized as already disturbed. Still, the most disturbed site by the simulated flow pulse appeared to be GB, the groundwater spring fed with less dynamic flow.

\section{CRediT authorship contribution statement}

Gemma Lobera and Isabel Pardo analyzed all the data and wrote the first draft of the paper.

Isabel Pardo, Liliana García, Ludmilla O. Ribeiro and Piet F.M. Verdonschot contributed in developing the monitoring design, carried out the fieldwork campaigns and post process all the samples.

Gemma Lobera, Isabel Pardo, Celso García, and Piet F.M. Verdonschot revised the final version of the paper.

\section{Declaration of competing interest}

The authors declare that they have no known competing financial interests or personal relationships that could have appeared to influence the work reported in this paper.

\section{Acknowledgements}

This article covers partial results obtained during a study on the application of the Water Framework Directive in temporary streams of the Balearic Islands. The financial support for this study was provided partially by the Agència Balear de l'Aigua i de la Qualitat Ambiental (Govern de les Illes Balears). Gemma Lobera has a Margalida Comas Fellowship funded by the Govern de les Illes Balears. We are grateful to Quico Sabater for providing the hyporheos sampler.

\section{Data availability statement}

Data will be made available upon reasonable request to the authors.

\section{Appendix A. Supplementary data}

Supplementary data to this article can be found online at https://doi. org/10.1016/j.scitotenv.2020.141843.

\section{References}

Álvarez, M., Pardo, I., 2007. Factors controlling epilithon biomass in a temporary, karstic stream: the interaction between substratum and grazing. J. N. Am. Benthol. Soc. 26 (2), 207-220.

Álvarez, M., Pardo, I., 2009. Dynamics in the trophic structure of the macroinvertebrate community in a Mediterranean, temporary stream. Aquat. Sci. 71, 202-213.

APHA, 1989. Standard Methods for the Examination of Water and Wastewater. Part 3. Determination of Metals, 17th American Public Health Association, Washington DC.

Arscott, D.B., Tockner, K., Ward, J.V., 2000. Aquatic habitat diversity along the corridor of an Alpine floodplain river (Fiume Tagliamento, Italy). Arch. Hydrobiol. 49 (4), 679-704.

Berg, M.A., Allen, D.M., 2008. Low flow variability in groundwater-fed streams. Can. Water Res. J. 32 (3), 227-246.

Biggs, B.J.F., Smith, R.A., Duncan, M.J., 1999. Velocity and sediment disturbance of periphyton in headwater streams: biomass and metabolism. J. N. Am. Benthol. Soc. 18, 222-241.

Bonada, N., Rieradevall, M., Prat, N., 2007. Macroinvertebrate community structure and biological traits related to flow permanence in a Mediterranean river network. Hydrobiologia 589, 91-106.

Boulton, A.J., Findlay, S., Marmonier, P., Stanley, E.H., Valett, H.M., 1998. The functional significance of the hyporheic zone in streams and rivers. Annu. Rev. Ecol. Systematics 29 $59-81$
Boulton, A.J., Harvey, M., Proctor, H., 2004. Of spates and species: responses by interstitial water mites to simulated spates in a subtropical Australian river. Appl. Exp. Acarol. 34, 149-169

Brittain, J.E., Eikeland, T.J., 1988. Invertebrate drift - a review. Hydrobiologia 166, 77-93. Brooks, S.S., Boulton, A.J., 1991. Recolonization dynamics of benthic macroinvertebrates after artificial and natural disturbances in an Australian temporary stream. Aust. J. Mar. Freshwat. Res. 42, 295-308.

Brouwer, J.H.F., Kraak, M.H.S., Besse-Lototskaya, A.A., Verdonschot, P.F.M., 2019. The significance of refuge heterogeneity for lowland stream caddisfly larvae to escape from drift. Sci. Rep. 9, 2140. https://doi.org/10.1038/s41598-019-38677-6.

Bussotti, F., Borghini, F., Celesti, C., Leonzio, C., Cozzi, A., Bettini, D., Ferretti, M., 2003. Leaf shedding, crown condition and element return in two mixed holm oakforests in Tuscany, central Italy. For. Ecol. Manag. 176, 273-285.

Candela, L., von Igel, W., Javier Elorza, F., Aronica, G., 2009. Impact assessment of combined climate and management scenarios on groundwater resources and associated wetland (Majorca, Spain). J. Hydrol. (37), 510-527.

Cherbuy, B., Joffre, R., Gillon, D., Rambal, S., 2001. Internal remobilization of carbohydrates, lipids, nitrogen and phosphorus in the Mediterranean evergreen oak Quercus ilex. Tree Physiol. 21, 9-17.

Cid, N., Verkaik, I., García-Roger, E.M., Rieradevall, M., Bonada, N., Sánchez-Montoya, M.M., Gómez, R., Suárez, M.L., Vidal-Abarca, M.R., Demartini, D., Buffagni, A., Erba, S., Karaouzas, I., Skoulikidis, N., Prat, N., 2016. A biological tool to assess flow connectivity in reference temporary streams from the Mediterranean Basin. Sci. Total Environ. $540,178-190$.

Clarke, K.R., 1993. Nonparametric multivariate analyses of changes in assemblage structure. Australian J. Ecol. 18, 117-143.

Clarke, K.R., Gorley, R.N., 2006. PRIMER v6: User Manual/tutorial. vol. 2006. PRIMER-E, Plymouth (192 pp.).

Cramer, W., Guiot, J., Fader, M., Garrabou, J., Gattuso, J.P., Iglesias, A., Lange, M.A., Lionello, P., Llasat, M.C., Paz, S., Peñuelas, J., Snoussi, M., Toreti, A., Tsimplis, M.N., Xoplaki, E., 2018. Climate change and interconnected risks to sustainable development in the Mediterranean. Nat. Clim. Chang. 8, 972-980.

Datry, T., Moya, N., Zubieta, J., Oberdorff, T., 2016a. Determinants of local and regional communities in intermittent and perennial headwaters of the Bolivian Amazon. Freshw. Biol. 61, 1335-1349.

Datry, T., Fritz, K., Leigh, C., 2016b. Challenges, developments and prespectives in intermittent river ecology. Freshw. Biol. 61, 1171-1180

Datry, T., Foulquier, A., Corti, R., von Schiller, D., Tockner, K., Mendoza-Lera, C., Zoppini, A., 2018. A global analysis of terrestrial plant litter dynamics in non-perennial waterways. Nat. Geosci. 11 (7), 497-503.

De Cáceres, M., Legendre, P., 2009. Associations between species and groups of sites: indices and statistical inference. Ecol 90, 3566-3574.

De Cáceres, M., Legendre, P., Moretti, M., 2010. Improving indicator species analysis by combining groups of sites. Oikos 119, 1674-1684.

De Cáceres, M., Legendre, P., Wiser, S.K., Brotons, Ll, 2012. Using species combinations in indicator value analyses. Methods Ecol. Evol. 3, 973-982.

Death, R.G., 2008. Effects of floods on aquatic invertebrate communities. In: Lancaster J. Briers, R.A. (Eds.), Aquatic Insects: Challenges to Populations. CAB International, Oxfordshire, UK, pp. 103-121.

Death, R.G., Winterbourn, M.J., 1995. Diversity patterns in stream benthic invertebrate communities: the influence of habitat stability. Ecol 76, 1446-1460.

Delucchi, C.M., 1989. Movement patterns of invertebrates in temporary and permanent streams. Oecologia 78, 199-207.

Descloux, S., Datry, T., Usseglio-Polatera, P., 2014. Trait based structure of invertebrates along a gradient of sediment colmation: benthos versus hyporheos responses. Sci. Total Environ. 466-467, 265-276.

Dole-Olivier, M.J., Marmonier, P., Beffy, J.L., 1997. Response of invertebrates to lotic disturbance: is the hyporheic zone a patchy refugium? Freshw. Biol. 37, 257-276.

Downes, B. Barmuta, L, Fairweather, P., Faith, D. 2002. Monitoring Ecological Impacts: Concepts and Practice in Flowing Waters. 2nd edn. Cambridge University Press, Cambridge.

Dufréne, M., Legendre, P., 1997. Species assemblages and indicator species: the need for a flexible asymmetrical approach. Ecol. Monogr. 67, 345-366.

Durkota, J.M., Wood, P.J., Johns, T., Thompson, J.R., Flower, R.J., 2019. Distribution of macroinvertebrate communities across surface and groundwater habitats in response to hydrological variability. Fund Appl Limnol 193. https://doi.org/10.1127/fal/2019/ 1156.

Fisher, S.G., Gray, L.J., Grimm, N.B., Busch, D.E., 1982. Temporal succession in a desert stream ecosystem following flash flooding. Ecol. Monogr. 52, 93-110.

Fraaije, R.G.A., ter Braak, C.J.F., Verduyn, B., Verhoeven, J.T.A., Soons, M.B., 2015. Dispersal versus environmental filtering in a dynamic system: drivers of vegetation patterns and diversity along stream riparian gradients. J. Ecol. 103, 1634-1646.

García, L., Pardo, I., 2017. Negative effects of stagnation and drought on benthic invertebrate communities in lowland streams. Mar. Freshw. Res. 68, 308-318.

García, L., Richardson, J.S., Pardo, I., 2012. Leaf quality influences invertebrate colonization and drift in a temperate rainforest stream. Can. J. Fish. Aquat. Sci. 69, 1663-1673.

García, L., Pardo, I., Delgado, C., 2014. Macroinvertebrate indicators of ecological status in Mediterranean temporary stream types of the Balearic Islands. Ecol. Indic. 45, 650-663.

Garcia, C., Gibbins, C.N., Pardo, I., Batalla, R.J., 2017. Long term flow change threatens invertebrate diversity in temporary streams: evidence from an island. Sci. Total Environ. 580, 1453-1459.

Gasith, A., Resh, V.H., 1999. Streams in Mediterranean climate regions: abiotic influences and biotic responses to predictable seasonal events. Annu. Rev. Ecol. Syst. 30, 51-81. 
Gerull, L., Frossard, A., Gessner, M.O., Mutz, M., 2012. Effects of shallow and deep sediment disturbance on whole-stream metabolism in experimental sand-bed flumes. Hydrobiologia 683, 297-310.

Gibbins, C., Vericat, D., Batalla, R.J., 2007. When is stream invertebrate drift catastrophic? The role of hydraulics and sediment transport in initiating drift during flood events. Freshw. Biol. 52, 2369-2384.

Greenwood, M.J., Booker, D.J., 2015. The influence of antecedent floods on aquatic invertebrate diversity, abundance and community composition. Ecohydrology 8, 188-203.

Grimm, N.B., Fisher, S.G., 1986. Nitrogen limitation in a Sonoran desert stream. J. N. Am. Benthol. Soc. 5 (1), 2.

Hershkovitz, Y., Gasith, A., 2013. Resistance, resilience, and community dynamics in mediterranean-climate streams. Hydrobiologia 719, 59-75.

Holomuzki, J.R., Biggs, B.J.F., 2000. Taxon-specific responses to high-flow disturbance in streams: implications for population persistence. J. N. Am. Benthol. Soc. 19, 670-679.

Holomuzki, J.R., Biggs, B.J., 2007. Physical microhabitat effects on 3-dimensional spatial variability of the hydrobiid snail, Potamopyrgus antipodarum. New Zeal. J. Mar. Freshw. Res. 41, 357-367.

Katz, S.B., Segura, C., Warren, D.R., 2017. The influence of channel bed disturbance on benthic chlorophyll a: A high resolution perspective. Geomorphology 305, 141-153.

Kobak, J., Jermacz, L., Marcinczyk, J., Bartoszynska, E., Rutkowska, D., Pawlowska, K., 2017. Abiotic factors affecting habitat selection by two invasive gammarids Dikerogammarus villosus and Pontogammarus robustoides. Hydrobiologia 797, 247-263.

Kruskal, J.B., 1964. Multidimensional scaling by optimizing goodness of fit to a nonmetric hypothesis. Psychometrika 29, 1-27.

Lake, P.S., 2000. Disturbance, patchiness, and diversity in streams. J. N. Am. Benthol. Soc. 19, 573-592.

Lake, P.S., 2003. Ecological effects of perturbation by drought in flowing waters. Freshw. Biol. 48, 1161-1172.

Leigh, C., Boulton, A.J., Courtwright, J.L., Fritz, K., May, C.L., Walker, R.H., Datry, T., 2016. Ecological research and management of intermittent rivers: an historical review and future directions. Freshw. Biol. 61, 1181-1199.

Leps, J., Smilauer, P., 2003. Multivariate Analysis of Ecological Data. Faculty of Biological Sciences. University of South Bohemia, Cesk Budejovice.

Lewandowski, J., Arnon, S., Banks, E., Batelaan, O., Betterle, A., Broecker, T., et al., 2019. Is the hyporheic zone relevant beyond the scientific community? Water 11, 2230. https://doi.org/10.3390/w11112230.

Lobera, G., Muñoz, I., López-Tarazón, J.A., Vericat, D., Batalla, R.J., 2017. Effects of flow regulation on river bed dynamics and invertebrate communities in a Mediterranean river. Hydrobiologia 784, 283-304.

Lobera, G., Pardo, I., García, L., García, C., 2019. Disentangling spatio-temporal drivers influencing benthic communities in temporary streams. Aquat. Sci. https://doi.org/ 10.1007/s00027-019-0664-X.

Lorenzen, C.J., 1967. Determination of chlorophyll and phaeopigments: spectrophotometric equations. Limnol. Oceanogr. 12, 342-346.

Lowe, R.L., Golladay, S., Webster, J., 1986. Periphyton response to nutrient manipulation in a clear-cut and forested watershed. J. N. Am. Benthol. Soc. 5, 211-220.

Malmqvist, B., Sjöström, P., 1987. Stream drift as a consequence of disturbance by invertebrate predators. Oecologia 74, 396-403.

Marchant, R., 1988. Vertical distribution of benthic invertebrates in the bed of the Thomson River, Victoria. Australian J. Mar. Freshw. Res. 39, 775-784.

Marchant, R., 1995. Seasonal variation in the vertical distribution of hyporheic invertebrates in an Australian upland river. Arch. Hydrobiol. 134, 441-457.

Marmonier, P., Creuzé des Châtelliers, M., 1991. Effects of spates on interstitial assemblages of the Upper Rhône River. Importance of spatial heterogeneity. Hydrobiologia 210, 243-251.

McMullen, L.E., Lytle, D.A., 2012. Quantifying invertebrate resistance to floods: a globalscale meta-analysis. Ecol. Appl. 22, 2164-2175.

Minshall, G.W., 1984. Aquatic insect-substratum relationships. In: Resh, V.H., Rosenberg, D.M. (Eds.), The Ecology of Aquatic Insects. Praeger Publishers, New York, pp. 358-400.
Naman, S.M., Rosenfeld, J.S., Richardson, J.S., Way, J.L., 2016. Species traits and channel architecture mediate flow disturbance impacts on invertebrate drift. Freshw. Biol. 62, 340-355.

Olsen, D.A., Townsend, C.R., 2005. Flood effects on invertebrates, sediments and particulate organic matter in the hyporheic zone of a gravel-bed stream. Freshw. Biol. 50, 839-853.

Pardo, I., Álvarez, M., 2006. Comparison of resource and consumer dynamics in Atlantic and Mediterranean streams. Limnetica 25, 271-286.

Poff, N.L., Olden, J.D., Vieira, N.K.M., Finn, D.S., Simmons, M.P., Kondratieff, B.C., 2006 Functional trait niches of North American lotic insects: traits-based ecological applications in light of phylogenetic relationships. J. N. Am. Benthol. Soc. 25, 730-755.

Resh, V.H., Bêche, L.A., Lawrence, J.E., Mazor, R.D., McElravy, E.P., O’Dowd, A.P., et al., 2013. Long term population and community patterns of benthic macroinvertebrates and fishes in Northern California Mediterranean-climate streams. Hydrobiologia 719, 93-118.

Robertson, A.L., Wood, P.J., 2010. Ecology of the hyporheic zone: origins, current knowledge and future directions. Fund. Appl. Limnol. 176, 279-289.

Sarremejane, R., Mykrä, H., Bonada, N., Aroviita, J., Muotka, T., 2017. Habitat connectivity and dispersal ability drive the assembly mechanisms of macroinvertebrate communities in river networks. Freshw. Biol. 62, 1073-1082.

Scarsbrook, M.R., 2002. Persistence and stability of lotic invertebrate communities in New Zealand. Freshw. Biol. 47, 417-431.

Schwarz, A.E., Schwoerbe, J., 1997. The aquatic processing of sclerophyilous and malacophyllous leaves on a Mediterranean island (Corsica): spatial and temporal pattern. Annu. Limnol. 33, 107-119.

Sen, P.K., 1968. Estimates of the regression coefficient based on Kendall's tau. J. Am. Stat Assoc. 63, 1379-1389.

Stubbington, R., 2012. The hyporheic zone as an invertebrate refuge: a review of variability in space, time, taxa and behaviour. Mar. Freshw. Res. 63, 293-311.

Stubbington, R., Wood, P.J., Reid, I., 2011. Spatial variability in the hyporheic zone refugium of temporary streams. Aquat. Sci. 73, 499-511.

Stubbington, R., Bogan, M.T., Bonada, N., Boulton, A.J., Datry, T., Leigh, C., Vander Vorste, R. 2017. The biota of intermittent rivers and ephemeral streams: aquatic invertebrates. In: Datry, T., Bonada, N., Boulton, A. (Eds.), Intermittent Rivers and Ephemeral Streams. Ecol. Manag.

Tachet, H., Richoux, P., Bournaud, M., Usseglio-Polatera, P., 2010. Invertébrés d'Eau Douce 3rd ed. CNRS, Paris.

Theil, H., 1950. A rank-invariant method of linear and polynomial regression analysis. I. Proc. Kon. Ned. Akad. v. Wetensch. A53, 386-392.

Tockner, K., Pennetzdorfer, D., Reiner, N., Schiemer, F., Ward, J.V., 1999. Hydrological connectivity, and the exchange of organic matter and nutrients in a dynamic riverfloodplain system (Danube, Austria). Freshw. Biol. 41, 521-535.

Townsend, C.R., Dolédec, S., Scarsbrook, M.R., 1997. Species traits in relation to tempora and spatial heterogeneity in streams: a test of habitat templet theory. Freshw. Biol. 37, 367-387.

Van den Brink, P.J., Ter Braak, C.J.F., 1999. Principal response curves: analysis of time dependent multivariate responses of a biological community to stress. Environ. Toxicol. Chem. 18, 138-148.

Van den Brink, P.J., den Bestern, P.J., de Vaate, A.B., Ter Braak, C.J.F., 2009. Principal response curves technique for the analysis of multivariate biomonitoring time series. Environ. Monit. Assess. 152, 271.

Vander Vorste, R., Malard, F., Datry, T., 2016. Is drift the primary process promoting the resilience of river invertebrate communities? A manipulative field experiment in an intermittent alluvial river. Freshw. Biol. 61, 1276-1292.

Williams, D.D., 2006. The Biology of Temporary Waters. Oxford University Press, Oxford.

Williams, D.D., Hynes, H.B.N., 1974. The occurrence of benthos deep in the substratum of a stream. Freshw. Biol. 4, 233-256.

Winterbottom, J.H., Orton, S.E., Hildrew, A.G., 1997. Field experiments on the mobility of benthic invertebrates in a southern English stream. Freshw. Biol. 38, 37-47. 